\title{
Synthesis, Structural Studies, and $\alpha$-Glucosidase Inhibitory, Antidiabetic, and Antioxidant Activities of 2,3-Dihydroquinazolin- 4(1H)-ones Derived from Pyrazol-4-carbaldehyde and Anilines
}

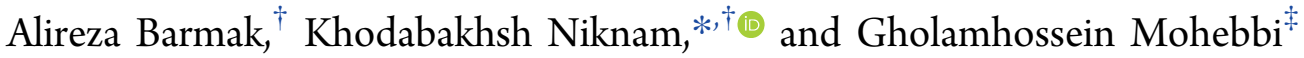 \\ ${ }^{\dagger}$ Department of Chemistry, Faculty of Sciences, Persian Gulf University, Bushehr 7516913817, Iran \\ ${ }^{\ddagger}$ The Persian Gulf Marine Biotechnology Research Center, the Persian Gulf Biomedical Research institute, Bushehr University of \\ Medical Sciences, Bushehr 7514763448, Iran
}

Supporting Information

\begin{abstract}
A series of new quinazoline derivatives were designed and synthesized via a one-pot condensation reaction between isatoic anhydride and aromatic aldehydes with anilines using aluminum sulfate as a catalyst in refluxing ethanol. Their structures were confirmed by their physical, IR, ${ }^{1} \mathrm{H}$ NMR, ${ }^{13} \mathrm{C}$ NMR, and mass spectroscopy data and evaluated for some biological effects, including the antioxidant and $\alpha$-glucosidase inhibitory activities as well as some in vivo hematological parameters. The ability of synthesized compounds in the inhibition of $\alpha$-glucosidase was also investigated through the in silico study. The significant and important changes in some hematological tests were perceived. Notably, compound $\mathbf{4 h}$ showed more reducing effects on cholesterol and triglyceride levels. This molecule certainly has the

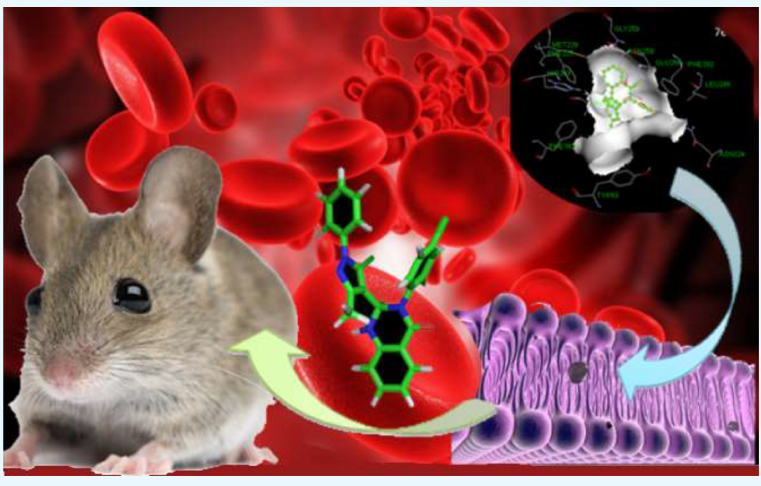
potential to be developed as the antihyperlipemic compound. The tested compounds, in particular, compounds $\mathbf{4 j}$ and $\mathbf{4 1}$, were found to be uniquely reducing blood sugar levels. The entire synthesized compounds showed the potent $\alpha$-glucosidase inhibitory activity compared with acarbose as a standard material. Amongst, the compounds $\mathbf{4 h}$ and $\mathbf{4 i}$ showed the strongest enzyme inhibitory potentials than the standard drug acarbose. There was a good correlation between in vitro and in silico studies for ligands $\mathbf{4 i}$ and $\mathbf{4 l}$. The majority of compounds presented a good radical scavenging activity, though the compound $\mathbf{4 j}$ exhibited the strongest activity, even to the standard of ascorbic acid. Further studies are required to determine whether these main compounds could be a potential treatment for diabetes and hyperlipidemia diseases.
\end{abstract}

\section{INTRODUCTION}

Diabetes mellitus is a non-infective metabolic disorder of multiple etiologies characterized by chronic hyperglycemia with conflicts of the protein, carbohydrate, and fat metabolism resulting from defects in insulin secretion, insulin action, or both. ${ }^{1}$ Normalization of blood glucose levels, especially postprandial hyperglycemia, is important to prevent the complications of diabetes, which include coronary heart disease, peripheral arteriopathy, retinopathy, neuropathy, and nephropathy. $^{2}$

Many natural and synthetic chemicals have been provided a potential source of anti-diabetic special effects and are extensively used for the treatment of diabetes mellitus in various modern and traditional systems of medicine worldwide. A lot of them are known to be effective against diabetes. ${ }^{3}$

In addition to adverse effects, many drugs that are presently used for the management of type 2 diabetes are not always satisfactory in maintaining normal levels of blood glucose and are facing limited efficacy and tolerability. ${ }^{4,5}$
$\alpha$-Glucosidase belongs to the glycosyl hydrolase 31 family of the hydrolases, and its major function is the hydrolysis of the terminal, non-reducing 1,4-linked $\alpha$-D-glucosidase with the release of $\alpha$-D-glucose. $\alpha$-Glucosidase has drawn special attention of the pharmaceutical research community since, in earlier studies, it was revealed that the inhibition of its catalytic activity resulted in the retardation of glucose absorption and decrease in postprandial blood glucose level. ${ }^{2} \alpha$-Glucosidase inhibitors play an important role to delay or inhibit the digestion or absorption of carbohydrates and suppress the postprandial hyperglycemia. ${ }^{6}$ Hence, they have broad aspects and many potentially expedient in the management of type 2 diabetes.

Heterocyclic compounds are of special interest to the medicinal chemists due to their unique biological properties. ${ }^{2}$ Nitrogen-containing heterocyclic compounds are the most abundant and integral scaffolds that occur entirely in a variety

Received: June 25, 2019

Accepted: October 10, 2019

Published: October 25, 2019 
Table 1. Optimization of the Reaction Conditions ${ }^{a}$

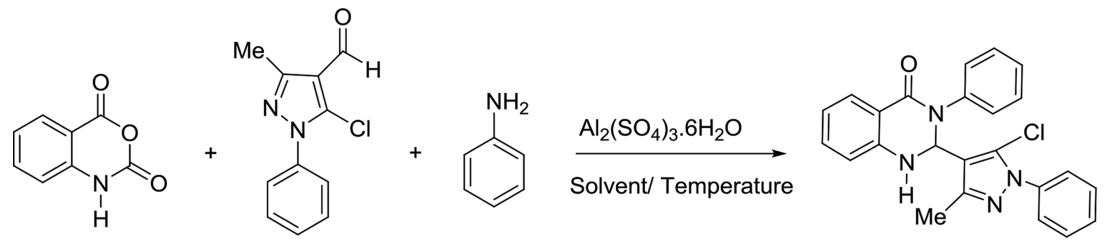

\begin{tabular}{|c|c|c|c|c|c|}
\hline entry & catalyst (mmol) & solvent & conditions & time (min) & yield $(\%)^{b}$ \\
\hline 1 & & ethanol & reflux & 600 & \\
\hline 2 & 0.01 & ethanol & R.T. & 80 & 32 \\
\hline 3 & 0.01 & ethanol & $40{ }^{\circ} \mathrm{C}$ & 80 & 60 \\
\hline 4 & 0.02 & ethanol & $55{ }^{\circ} \mathrm{C}$ & 80 & 72 \\
\hline 5 & 0.02 & ethanol & $65^{\circ} \mathrm{C}$ & 80 & 74 \\
\hline 6 & 0.02 & ethanol & reflux & 80 & 78 \\
\hline 7 & 0.02 & $n$-hexane & reflux & 80 & 70 \\
\hline 8 & 0.02 & water & $80{ }^{\circ} \mathrm{C}$ & 80 & 20 \\
\hline 9 & 0.02 & methanol/water (50:50) & $80{ }^{\circ} \mathrm{C}$ & 80 & 53 \\
\hline 10 & 0.02 & ethyl acetate & reflux & 80 & 60 \\
\hline 11 & 0.04 & ethanol & reflux & 80 & 82 \\
\hline 12 & 0.06 & ethanol & reflux & 80 & 88 \\
\hline 13 & 0.07 & ethanol & reflux & 80 & 89 \\
\hline 14 & 0.06 & ethanol & reflux & 80 & $55^{c}$ \\
\hline 15 & $0.006 \mathrm{~g}$ & ethanol & reflux & 80 & $43^{d}$ \\
\hline
\end{tabular}

${ }^{a}$ Reaction conditions: isatoic anhydride $(1 \mathrm{mmol})$, 5-chloro-3-methyl-1-phenylpyrazole-4-carbaldehyde ( $\left.1 \mathrm{mmol}\right)$, aniline $(1 \mathrm{mmol})$, and solvent $(5$ $\mathrm{mL})$. R.T., room temperature. ${ }^{b}$ Isolated yield. ${ }^{c}$ The reaction was catalyzed by $\mathrm{AlCl}_{3}(0.06 \mathrm{mmol}) .{ }^{d}$ The reaction was catalyzed by acidic alumina $(0.006 \mathrm{~g})$.

of synthetic drugs, bioactive natural products, and pharmaceuticals. ${ }^{7}$ The presence of $\mathrm{N}$-heterocycles as an essential structural motif in a variety of biologically active substances has stimulated the development of the novel technologies and strategies for their synthesis. Among the $\mathrm{N}$-containing heterocycles, quinazolinone is a building block of approximately 200 naturally occurring alkaloids isolated to date from a number of plants, microorganisms, and animals. ${ }^{7}$ The first quinazolinone was synthesized in the late 1860s from cyanogens and anthranilic acid to give 2-cyanoquinazolinone. ${ }^{8}$

On a quest to find further potential quinazolinone-based drugs, various substituted quinazolinones have been synthesized. ${ }^{9}$ The quinazolinone derivatives have shown various biological activities such as antimalarial, ${ }^{10}$ anticancer, ${ }^{11}$ antiHIV, ${ }^{12}$ antimicrobial, ${ }^{13}$ anti-inflammatory, ${ }^{14}$ antitubercular, ${ }^{15}$ antihypertensive, ${ }^{16}$ and cholinesterase inhibition ${ }^{17}$ activities. This broad spectrum of effects has been further facilitated by the synthetic versatility of quinazolinones, which authorizes the generation of numerous structurally various molecules. ${ }^{18}$ The antidiabetic $^{19}$ and antioxidant ${ }^{13}$ activities of these compounds were also appraised. ${ }^{20,21}$

Considering the importance of these compounds, several methods have been revealed for the synthesis of 2,3dihydroquinazolin-4(1H)-ones. They are usually synthesized by three-component reactions of aldehydes, isatoic anhydrides, primary amines, or ammonium salts, in the presence of numerous catalysts, under different circumstances. ${ }^{22-25}$ Some of these reagents or catalysts are cerium(IV) sulfate, ${ }^{26}(\mathrm{Cu}-$ CNTs), ${ }^{27}$ choline chloride in the presence of malonic acid, ${ }^{28}$ silica-bonded propyl-S-sulfonic acid (SBSSA), ${ }^{29}$ silica-bonded $\mathrm{N}$-propyl sulfamic acid (SBNPSA), ${ }^{30}$ and $\mathrm{Al}\left(\mathrm{H}_{2} \mathrm{PO}_{4}\right)_{3} \cdot{ }^{31}$ Some of these methods have limitations such as long reaction time, high-temperature reaction, side reactions producing a mixture of products and complex separation, and purification methods. In the current study, we developed the synthesis of 2,3-
dihydroquinazolin-4(1H)-ones in the presence of aluminum sulfate $\left(\mathrm{Al}_{2}\left(\mathrm{SO}_{4}\right)_{3} \cdot 6 \mathrm{H}_{2} \mathrm{O}\right)$ as a catalyst in ethanol. Furthermore, pyrazol-quinazolinones as the new derivatives of quinazolinones were synthesized by replacing aromatic aldehyde with pyrazole4-carbaldehyde (compounds 4g-41). Moreover, our catalystbased method has benefits such as having less reaction time, high performance, and environmental compatibility and being a lowcost catalyst and nontoxic.

Free radicals are reactive chemicals that are short-lived species having one or more unpaired electrons. They induce injury to organism cells by a small increase in the unpaired electron resulting in cell biomolecules oxidation. ${ }^{32}$

One possible hypothesis in diabetes is that the disease state leads to an increase in active oxygen species production. In addition to the starring role of oxidative stress in the onset of diabetes, it seems to play a key role in chronic complications of the disease. It has been reported that the free radical scavengers are effective in avoiding diabetes in animal models. ${ }^{33-36}$ However, recent shreds of evidence have revealed that firstline therapy for cardiovascular disease prevention and the most important lipid-lowering drugs such as statins can increase the risk of new-onset diabetes. ${ }^{37,38}$ It is assumed to have a direct correlation between antidiabetic and antioxidant potentials of compounds. A number of studies revealed that a compound exhibiting a higher glucose-lowering effect appears to have a good antioxidant potential as well. ${ }^{39-42}$ Moreover, it has been alleged that some drugs can alter normal hematological values. $^{43,44}$ Hence, the hematological parameters could be a crucial factor in their toxic effect evaluations; ${ }^{45}$ though, it is believed that some antioxidant agents can combat oxidative stress and improve the hematological status. ${ }^{46}$ Clinically, it is needed to develop the new therapeutic approaches with the novel generation of drugs lacking these side effects. Here, in this study, we are reporting the synthesis of some new derivatives of quinazolines and their hematological and antioxidant activities, 
$\alpha$-glucosidase inhibitory potential, and molecular docking studies.

\section{RESULTS AND DISCUSSION}

The catalytic activity of aluminum sulfate $\left(\mathrm{Al}_{2}\left(\mathrm{SO}_{4}\right)_{3} \cdot 6 \mathrm{H}_{2} \mathrm{O}\right)$ was investigated in the synthesis of 2,3-dihydroquinazolinones via a one-pot three-component condensation reaction between aromatic aldehydes and isatoic anhydride with aniline derivatives. In a preliminary study, the reaction of isatoic anhydride and 5-chloro-3-methyl-1-phenylpyrazole-4-carbaldehyde with aniline was selected as a model reaction in refluxing ethanol (Table 1). To illustrate the need of $\mathrm{Al}_{2}\left(\mathrm{SO}_{4}\right)_{3} \cdot 6 \mathrm{H}_{2} \mathrm{O}$ for this condensation, we examined the model reaction in the absence of $\mathrm{Al}_{2}\left(\mathrm{SO}_{4}\right)_{3} \cdot 6 \mathrm{H}_{2} \mathrm{O}$ in refluxing ethanol (Table 1, entry 1). The results exhibit clearly that $\mathrm{Al}_{2}\left(\mathrm{SO}_{4}\right)_{3} \cdot 6 \mathrm{H}_{2} \mathrm{O}$ is an effective catalyst for this transformation, and in the absence of $\mathrm{Al}_{2}\left(\mathrm{SO}_{4}\right)_{3} \cdot 6 \mathrm{H}_{2} \mathrm{O}$, the reaction did not take place even after $10 \mathrm{~h}$. Also, when we used other aluminum species such as aluminum trichloride and acidic alumina as a catalyst, the corresponding product was obtained in low yields (Table 1, entries 14 and 15). As indicated in Table 1, the best results were obtained with 0.06 mmol of $\mathrm{Al}_{2}\left(\mathrm{SO}_{4}\right)_{3} \cdot 6 \mathrm{H}_{2} \mathrm{O}$ in refluxing ethanol (Table 1, entry 12).

In order to synthesize 2,3-dihydroquinazolinones, the reaction between aromatic aldehydes (2) and isatoic anhydride with aniline derivatives (3) was investigated under optimized conditions. As shown in Table 2, aniline derivatives such as 4hydroxyaniline, 3-chloroaniline, and 4-methylaniline and those treated with aromatic aldehydes and isatoic anhydride and corresponding products were obtained in good to high yields. The novel classes of pyrazol-quinazolinones were synthesized by replacing 5-chloro-3-methyl-1-phenyl-1H-pyrazole-4-carbaldehyde instead of aromatic aldehyde. These new derivatives were achieved in good to high yields under optimized reaction conditions.

According to Table 2, the desired product was well reached by aromatic aldehydes with the electron donor and acceptor substituents under reaction conditions. On the other hand, this reaction was carried out well and raced up by aromatic amines due to their high nucleophilic power. The recommended mechanism to provide the 2,3-dihydroquinazolin-4 $(1 \mathrm{H})$-ones by $\mathrm{Al}_{2}\left(\mathrm{SO}_{4}\right)_{3} \cdot 6 \mathrm{H}_{2} \mathrm{O}$ as the catalyst is shown in Figure 1 . First, the catalyst activated the carbonyl isatoic anhydride group to get the compound ready for an amine group attack. This is due to the $\mathrm{C}-\mathrm{O}$ bond breaking in the carbonyl group and forming the intermediate (i). Consequently, a $\mathrm{CO}_{2}$ molecule and catalyst left the compound, and an intermediate was attained (ii). Then, the catalyst-activated aldehyde group was attacked by an ammonium nitrogen lone pair and compound (iii) was obtained. To summarize, the product was obtained by hydrogen displacement and ring formation.

Spectral Data for New Compounds.<smiles>Cc1nn(-c2ccccc2)c(Cl)c1C1Nc2ccccc2C(=O)N1c1ccccc1</smiles>

Table 2. Synthesis of 2,3-Disubstituted-2,3Dihydroquinazolin-4 $(1 \mathrm{H})$-ones by Reaction of Isatoic Anhydride with Aldehydes and Primary Amines ${ }^{a}$

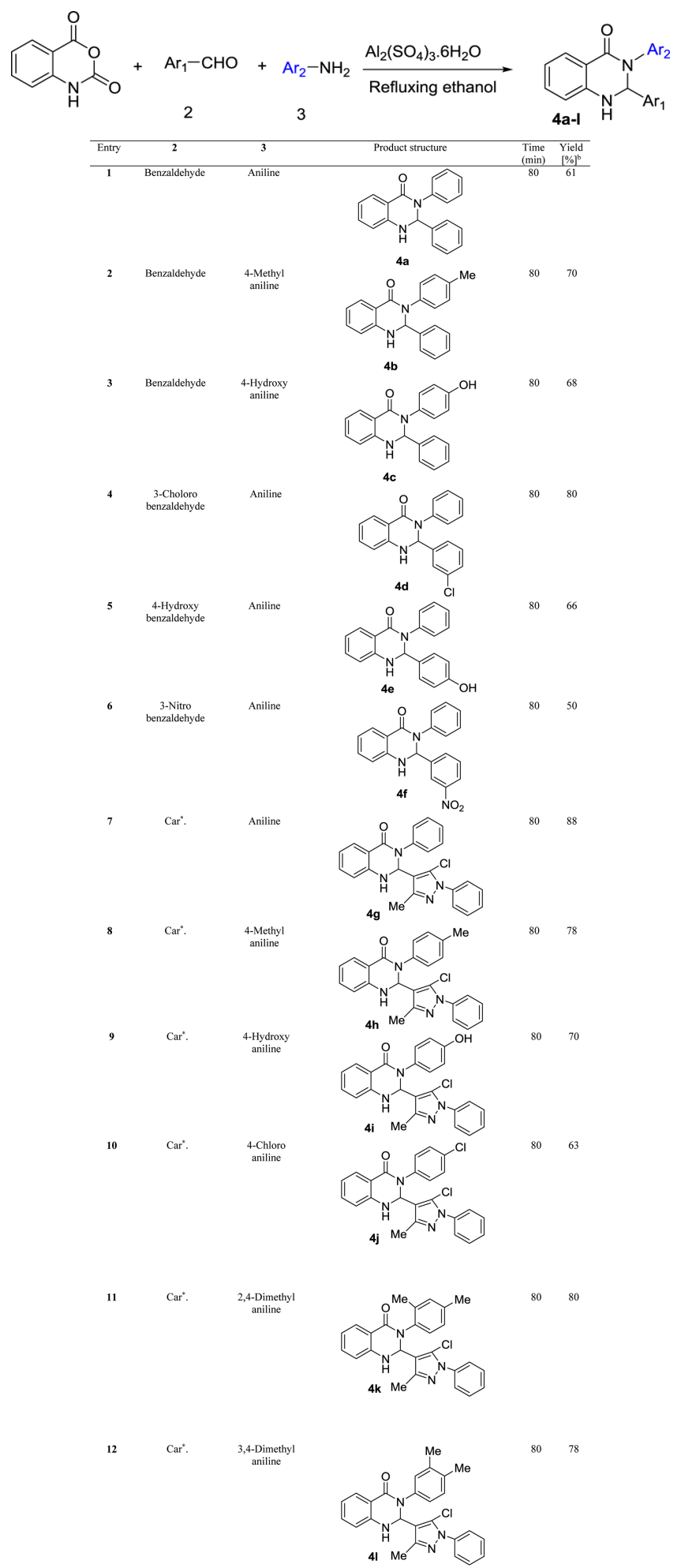

${ }^{a}$ Reaction conditions: isatoic anhydride $(1 \mathrm{mmol})$, aniline $(1 \mathrm{mmol})$, aldehyde $(1 \mathrm{mmol})$, and solvent $5 \mathrm{~mL}$. ${ }^{b}$ Isolated yield. Car*. = 5chloro-3-methyl-1-phenylpyrazole-4-carbaldehyde.

2-(5-Chloro-3-methyl-1-phenyl-1H-pyrazol-4-yl)-3-phenyl2,3-dihydroquinazolin-4(1H)-one (4g) (Table 2, Entry 7). Isolated yield $=88 \%$. White color. $\mathrm{mp} 216-218^{\circ} \mathrm{C}$. IR $(\mathrm{KBr})$ : 

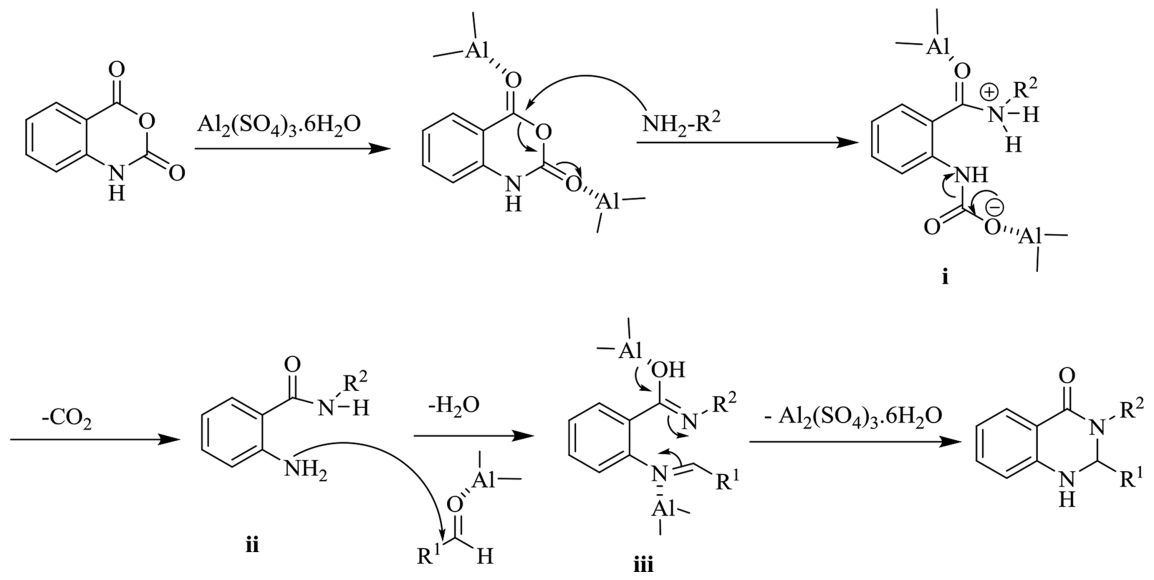

Figure 1. Mechanism of the synthesis of 2,3-dihydroquinazolin-4(1H)-ones.

$3305(\mathrm{~N}-\mathrm{H}), 1684(\mathrm{~N}-\mathrm{C}=\mathrm{O}) \mathrm{cm}^{-1} .{ }^{1} \mathrm{H}$ NMR $(300 \mathrm{MHz}$, DMSO-d $d_{6} \delta(\mathrm{ppm}): 2.23(\mathrm{~s}, 1 \mathrm{H}), 6.47(\mathrm{~s}, 1 \mathrm{H}), 6.75-6.81(\mathrm{~m}$, $2 \mathrm{H}), 7.19-7.22(\mathrm{~m}, 3 \mathrm{H}), 7.28-7.35(\mathrm{~m}, 6 \mathrm{H}), 7.45(\mathrm{t}, J=7.4$ $\mathrm{Hz}, 1 \mathrm{H}), 7.50(\mathrm{t}, J=7.8 \mathrm{~Hz}, 2 \mathrm{H}), 7.72(\mathrm{~d}, J=7.8 \mathrm{~Hz}, 1 \mathrm{H}) ;{ }^{13} \mathrm{C}$ NMR (75 MHz, DMSO- $\left.d_{6}\right) \delta(\mathrm{ppm}): 13.8,66.6,114.8,115.2$, $115.6,118.1,125.2,126.8,127.5,128.3,128.5,128.9,129.0$, 129.8, 134.2, 137.8, 140.3, 148.4, 149.0, 163.9. Anal. Calcd. for $\mathrm{C}_{24} \mathrm{H}_{19} \mathrm{ClN}_{4} \mathrm{O} ; \mathrm{C}, 69.48 ; \mathrm{H}, 4.62 ; \mathrm{Cl}, 8.54 ; \mathrm{N}, 13.50 \%$. Found $\mathrm{C}$, 69.17; H, 4.73; N, 13.21\%. MS $(m / z): 414\left(\mathrm{M}^{+}\right), 323$ (base peak).<smiles>Cc1ccc(N2C(=O)c3ccccc3NC2c2c(C)nn(-c3ccccc3)c2Cl)cc1</smiles>

2-(5-Chloro-3-methyl-1-phenyl-1H-pyrazol-4-yl)-3-(ptolyl)-2,3-dihydroquinazolin-4(1H)-one (4h) (Table 2, Entry 8). Isolated yield $=78 \%$. Yellow color. $\mathrm{mp} 190-192{ }^{\circ} \mathrm{C}$. IR $(\mathrm{KBr}): 3289(\mathrm{~N}-\mathrm{H}), 1630(\mathrm{~N}-\mathrm{C}=\mathrm{O}) \mathrm{cm}^{-1} .{ }^{1} \mathrm{H}$ NMR $(300$ $\left.\mathrm{MHz}, \mathrm{CDCl}_{3}\right) \delta(\mathrm{ppm}): 2.32(\mathrm{~s}, 3 \mathrm{H}), 2.39(\mathrm{~s}, 3 \mathrm{H}), 6.40(\mathrm{~s}, 1 \mathrm{H})$, $6.73(\mathrm{~d}, J=7.8 \mathrm{~Hz}, 1 \mathrm{H}), 6.92(\mathrm{t}, J=7.4 \mathrm{~Hz}, 1 \mathrm{H}), 7.08-7.14(\mathrm{~m}$, $4 \mathrm{H}), 7.30-7.50(\mathrm{~m}, 7 \mathrm{H}), 8.05(\mathrm{~d}, J=7.8 \mathrm{~Hz}, 1 \mathrm{H}) ;{ }^{13} \mathrm{C} \mathrm{NMR}$ $\left(75 \mathrm{MHz} \mathrm{CDCl}_{3}\right) \delta(\mathrm{ppm}): 13.9,21.1,67.0,114.4,114.7,116.6$, $119.7,124.9,127.1,128.5,129.1,129.3,129.5,129.6,133.8$, 136.7, 137.2, 137.7, 146.7, 149.0, 164.3. Anal. Calcd. for $\mathrm{C}_{25} \mathrm{H}_{21} \mathrm{ClN}_{4} \mathrm{O} ; \mathrm{C}, 70.01 ; \mathrm{H}, 4.94 ; \mathrm{Cl}, 8.26 ; \mathrm{N}, 13.06 \%$. Found C, 69.68; H, 4.90; N, 12.72\%. MS (m/z): $428\left(\mathrm{M}^{+}\right), 429\left(\mathrm{M}^{+}+1\right.$, base peak).<smiles>Cc1nn(-c2ccccc2)c(Cl)c1C1Nc2ccccc2C(=O)N1c1ccc(O)cc1</smiles>

2-(5-Chloro-3-methyl-1-phenyl-1H-pyrazol-4-yl)-3-(4-hydroxyphenyl)-2,3-dihydroquinazolin-4(1H)-one (4i) (Table 2, Entry 9). Isolated yield $=70 \%$. White color. $\mathrm{mp} 236-238^{\circ} \mathrm{C}$. IR $(\mathrm{KBr}): 3305(\mathrm{~N}-\mathrm{H}), 1615(\mathrm{~N}-\mathrm{C}=\mathrm{O}) \mathrm{cm}^{-1} \cdot{ }^{1} \mathrm{H}$ NMR $(300$ $\left.\mathrm{MHz}, \mathrm{DMSO}-d_{6}\right) \delta(\mathrm{ppm}): 2.24(\mathrm{~s}, 3 \mathrm{H}), 6.73(\mathrm{~s}, 1 \mathrm{H}), 6.65-$ $6.82(\mathrm{~m}, 4 \mathrm{H}), 7.00(\mathrm{~d}, J=8.4 \mathrm{~Hz}, 2 \mathrm{H}), 7.30-7.37(\mathrm{~m}, 4 \mathrm{H})$, $7.44-7.56(\mathrm{~m}, 3 \mathrm{H}), 7.74(\mathrm{~d}, J=6.9 \mathrm{~Hz}, 1 \mathrm{H}), 9.50(\mathrm{brs}, 1 \mathrm{H}) ;{ }^{13} \mathrm{C}$ NMR (75 MHz, DMSO- $\left.d_{6}\right) \delta$ (ppm): 13.8, 66.8, 114.7, 115.2, $115.5,115.8,117.9,125.1,126.8,128.5,128.9,129.3,129.8$, 131.4, 134.0, 137.8, 148.4, 149.0, 156.6, 164.0. Anal. Calcd. for $\mathrm{C}_{24} \mathrm{H}_{19} \mathrm{ClN}_{4} \mathrm{O}_{2} ; \mathrm{C}, 66.90 ; \mathrm{H}, 4.44 ; \mathrm{Cl}, 8.23 ; \mathrm{N}, 13.00 \%$. Found C, 66.56; H, 4.49; N, 12.74\%. MS (m/z): $430\left(\mathrm{M}^{+}\right), 431\left(\mathrm{M}^{+}+\right.$ 1 , base peak).<smiles>Cc1nn(-c2ccccc2)c(Cl)c1C1Nc2ccccc2C(=O)N1c1ccc(Cl)cc1</smiles>

2-(5-Chloro-3-methyl-1-phenyl-1H-pyrazol-4-yl)-3-(4chlorophenyl)-2,3-dihydroquinazolin-4(1H)-one (4j) (Table 2 , Entry 10). Isolated yield $=63 \%$. Orange color. $\mathrm{mp} 219-221$ ${ }^{\circ} \mathrm{C}$. IR (KBr): $1613(\mathrm{~N}-\mathrm{C}=\mathrm{O}) \mathrm{cm}^{-1} .{ }^{1} \mathrm{H}$ NMR $(300 \mathrm{MHz}$, $\left.\mathrm{CDCl}_{3}\right) \delta(\mathrm{ppm}): 2.38(\mathrm{~s}, 3 \mathrm{H}), 6.43(\mathrm{~s}, 1 \mathrm{H}), 6.76(\mathrm{~d}, J=8.1 \mathrm{~Hz}$, $1 \mathrm{H}), 6.98(\mathrm{t}, J=7.5 \mathrm{~Hz}, 1 \mathrm{H}), 7.12-7.16(\mathrm{~m}, 1 \mathrm{H}), 7.22-7.29$ $(\mathrm{m}, 4 \mathrm{H}), 7.36-7.52(\mathrm{~m}, 6 \mathrm{H}), 8.05\left(\mathrm{dd}, J_{1}=7.0 \mathrm{~Hz}, J_{2}=1.2 \mathrm{~Hz}\right.$, $1 \mathrm{H}), ;{ }^{13} \mathrm{C}$ NMR (125 MHz, DMSO- $\left.d_{6}\right) \delta(\mathrm{ppm}): 13.3,66.1$, $114.4,114.7,115.1,117.7,124.7,126.4,127.0,127.8,128.1$, 128.4, 128.5, 129.3, 133.8, 137.3, 139.8, 147.9, 148.5, 163.4. Anal. Calcd. for $\mathrm{C}_{24} \mathrm{H}_{18} \mathrm{Cl}_{2} \mathrm{~N}_{4} \mathrm{O} ; \mathrm{C}, 64.15 ; \mathrm{H}, 4.04 ; \mathrm{Cl}, 15.78 ; \mathrm{N}$, $12.47 \%$. Found C, 63.79; H, 4.13; N, $12.11 \%$. MS $(m / z): 449$ $\left(\mathrm{M}^{+}\right.$, base peak), $450\left(\mathrm{M}^{+}+1\right), 451\left(\mathrm{M}^{+}+2\right)$. 
Table 3. Inhibition Percent (\%) Values of Different Concentrations $\left(\mu \mathrm{g} \mathrm{mL}^{-1}\right)$ of the Tested Substances $(4 \mathrm{~g}-4 \mathrm{l})$ and Ascorbic Acid (AA) as a Standard Antioxidant Obtained from the DPPH Scavenging Assay

\begin{tabular}{|c|c|c|c|c|c|c|c|}
\hline \multirow[b]{2}{*}{ conc. $\left(\mu \mathrm{g} \mathrm{mL}^{-1}\right)$} & \multicolumn{6}{|c|}{ compound } & \multirow[b]{2}{*}{$\mathrm{AA}$} \\
\hline & $4 g$ & $4 h$ & $4 i$ & $4 j$ & $4 k$ & 41 & \\
\hline 0.2 & $20.71 \pm 0.2$ & $11.42 \pm 0.03$ & $80.07 \pm 0.77$ & $79.9 \pm 0.9$ & $67.72 \pm 0.2$ & $60.14 \pm 0.1$ & $53.13 \pm 0.7$ \\
\hline 0.4 & $20.32 \pm 0.2$ & $11.44 \pm 0.02$ & $81.18 \pm 0.5$ & $87.68 \pm 0.7$ & $67.80 \pm 0.3$ & $60.19 \pm 0.2$ & $61.22 \pm 0.7$ \\
\hline 0.6 & $20.51 \pm 0.1$ & $11.46 \pm 0.02$ & $83.9 \pm 0.1$ & $93.58 \pm 1$ & $67.87 \pm 0.1$ & $60.25 \pm 0.2$ & $69.18 \pm 1$ \\
\hline 0.8 & $21.16 \pm 0.1$ & $11.48 \pm 0.04$ & $85.62 \pm 0.3$ & $99.37 \pm 0.7$ & $67.95 \pm 0.2$ & $60.30 \pm 0.1$ & $88.47 \pm 0.9$ \\
\hline 1.0 & $20.62 \pm 0.5$ & $11.50 \pm 0.07$ & $86.47 \pm 0.27$ & $102 \pm 2$ & $68.03 \pm 0.1$ & $60.35 \pm 0.2$ & $98.03 \pm 2$ \\
\hline
\end{tabular}<smiles>Cc1ccc(N2C(=O)c3ccccc3NC2c2c(C)nn(-c3ccccc3)c2Cl)c(C)c1</smiles>

2-(5-Chloro-3-methyl-1-phenyl-1H-pyrazol-4-yl)-3-(2,4-dimethylphenyl)-2,3-dihydroquinazolin-4(1H)-one (4k) (Table 2 , Entry 11). Isolated yield $=80 \%$. White color. $\mathrm{mp} 202^{\circ} \mathrm{C}$. IR (KBr): $3283(\mathrm{~N}-\mathrm{H}), 1612(\mathrm{~N}-\mathrm{C}=\mathrm{O}) \mathrm{cm}^{-1} .{ }^{1} \mathrm{H}$ NMR $(400$ $\left.\mathrm{MHz}, \mathrm{CDCl}_{3}\right) \delta(\mathrm{ppm}): 2.16(\mathrm{~s}, 6 \mathrm{H}, \mathrm{Me}), 2.22(\mathrm{~s}, 3 \mathrm{H}, \mathrm{Me}), 6.41$ (s, 1H, CH), 6.75-6.81 (m, 2H, Ar), $6.91(\mathrm{~d}, J=6.4 \mathrm{~Hz}, 1 \mathrm{H}$, Ar), 6.99 (s, 1H, NH), 7.05 (d, J = 6.4 Hz, 1H, Ar), 7.28-7.34 (m, 4H, Ar), 7.43-7.53 (m, 4H, Ar), 7.73 (d, J=6.4 Hz, 1H, Ar). ${ }^{13} \mathrm{C}-\mathrm{NMR}\left(125 \mathrm{MHz}, \mathrm{DMSO}-d_{6}\right) \delta$ (ppm): 13.3, 18.9, 19.2, $66.0,114.3,114.9,115.3,117.5,124.6,124.8,124.9,126.3$, $128.0,128.4,128.5,129.3,133.5,134.8,136.2,137.2,137.3$, 147.8, 148.4, 163.2. Anal. Calcd. for $\mathrm{C}_{26} \mathrm{H}_{23} \mathrm{ClN}_{4} \mathrm{O}_{2} ; \mathrm{C}$, 70.50; $\mathrm{H}, 5.23 ; \mathrm{Cl}, 8.00 ; \mathrm{N}, 12.65 \%$. Found $\mathrm{C}, 70.21 ; \mathrm{H}, 5.34 ; \mathrm{N}$, $12.43 \%$. MS $(m / z): 442\left(\mathrm{M}^{+}\right), 57$ (base peak).<smiles>Cc1ccc(N2C(=O)c3ccccc3NC2c2c(C)nn(-c3ccccc3)c2Cl)cc1C</smiles>

2-(5-Chloro-3-methyl-1-phenyl-1H-pyrazol-4-yl)-3-(3,4-dimethylphenyl)-2,3-dihydroquinazolin-4(1H)-one (4I) (Table 2, Entry 12). Isolated yield $=78 \%$. White color. $\mathrm{mp} 201-203{ }^{\circ} \mathrm{C}$. IR (KBr): $3299(\mathrm{~N}-\mathrm{H}), 1645(\mathrm{~N}-\mathrm{C}=\mathrm{O}) \mathrm{cm}^{-1} .{ }^{1} \mathrm{H}$ NMR $\left(500 \mathrm{MHz}, \mathrm{DMSO}-d_{6}\right): 2.15(\mathrm{~s}, 6 \mathrm{H}), 2.21(\mathrm{~s}, 3 \mathrm{H}), 6.40(\mathrm{~s}, 1 \mathrm{H})$, 6.74-6.78 (m, 2H) ,6.88-6.90 (m, 1H), $6.98(\mathrm{~s}, 1 \mathrm{H}), 7.04(\mathrm{~d}, J$ $=8.0 \mathrm{~Hz}, 1 \mathrm{H}), 7.27-7.33(\mathrm{~m}, 4 \mathrm{H}), 7.43-7.46(\mathrm{~m}, 1 \mathrm{H}), 7.50-$ $7.53(\mathrm{~m}, 2 \mathrm{H}), 7.71(\mathrm{~d}, J=8.0 \mathrm{~Hz}, 1 \mathrm{H}) .{ }^{13} \mathrm{C} \mathrm{NMR}(75 \mathrm{MHz}$, DMSO- $\left.d_{6}\right)$ : $13.8,19.4,19.7,66.5,114.8,115.3,115.8,118.0$, $125.1,125.3,126.8,128.5,129.0,129.8,134.1,136.3,136.7$, 137.7, 137.8, 148.4, 148.9, 163.8. Anal. Calcd. for $\mathrm{C}_{26} \mathrm{H}_{23} \mathrm{ClN}_{4} \mathrm{O}_{2} ; \mathrm{C}, 70.50 ; \mathrm{H}, 5.23 ; \mathrm{Cl}, 8.00 ; \mathrm{N}, 12.65 \%$. Found
C, 70.16; H, 5.32; N, 12.48\%. MS $(m / z): 442\left(\mathrm{M}^{+}\right), 279$ (base peak).

Biological Activities. From the newly synthesized compounds, to study the donor-acceptor substituent effects on some biological activities, the compounds $4 \mathrm{~g}, 4 \mathrm{~h}, 4 \mathbf{i}, 4 \mathbf{j}, 4 \mathrm{k}$, and 41 were selected.

Antioxidant Activity. Recently, antioxidants have attracted much attention in relation to oxidative stress and radicals, cancer prophylaxis and therapy, and longevity. ${ }^{47}$ To study the free radical scavenging ability of the synthesized compounds $(4 \mathrm{~g}-$ 41), the DPPH [diphenyl-(2,4,6-trinitrophenyl)iminoazanium] assay was used. The DPPH assay method is based on reduction of DPPH, a stable free radical. ${ }^{48}$ The results are presented in Table 3.

All compounds presented the good radical scavenging in a dose-dependent manner at concentrations of $0.2-1.0 \mu \mathrm{M}$ compared to the control group (Table 3 ), while the compound $4 \mathbf{j}$ showed strong inhibitory activity, stronger than ascorbic acid as a standard. This compound showed a significant inhibitory effect with the increase in concentrations $(p<0.05)$ but not statistically significant between concentrations of 0.8 and $1 \mu \mathrm{g} /$ $\mathrm{mL}$. This is probably due to the greater involvement of chlorine substitution in free radical stabilization in the relevant doses. The second potent compound was $4 \mathbf{i}(80.07 \pm 0.77$ to $86.47 \pm$ $0.27 \%)$. This was followed by compounds $4 \mathrm{k}, \mathbf{4 l}, \mathbf{4 g}$, and $4 \mathrm{~h}$ in different concentrations. In these four compounds, the inhibition values showed a transient increase, with a mild gradient in a dose-dependent manner.

The most and least inhibition values were associated with 4-Cl and 4-Me substrates, respectively, and then, the higher inhibitory activities were observed in rings with $-\mathrm{Cl}$ as an acceptor substitute in comparison to $\mathrm{Me}$ as the donor. This may be due to the stability of the electric charge throughout the component $\mathrm{DPPH}$ by the acceptor agent $(\mathrm{Cl})$, where, in $\mathrm{Me}$, the substrate charge becomes unstable after mixing two molecules.

The formed free radical is well stable owing to the proper location of chlorine for the electron-withdrawing effect in the para position. This belongs to the inductive effect of electronwithdrawing groups. However, in our other structures with electron-donating groups, the stereoelectronic effect of the phenyl ring is the main reason for the competition between the inductive effect and electron cloud deployment. Electron cloud deployment further demonstrates its effect on free radical stability.

Generally, the antioxidant capacity depends on several particular structural properties, such as the electronegativity, position, and number of functional groups in the antioxidant molecule. Therefore, the choice of models with particular functional groups for measuring the antioxidant capacity influences the results. Among the abovementioned contents, the higher antioxidant content of compound $4 \mathrm{k}$ rather than $4 \mathrm{~h}$ can be due to the position of functional groups in the molecule 
$\mathbf{4 k} .{ }^{49}$ As shown in Figure 2, the phenyl ring in compound $\mathbf{4 k}$ has less free rotation around the $\mathrm{C}-\mathrm{N}$ bond than the $4 \mathrm{~h}$ structure.

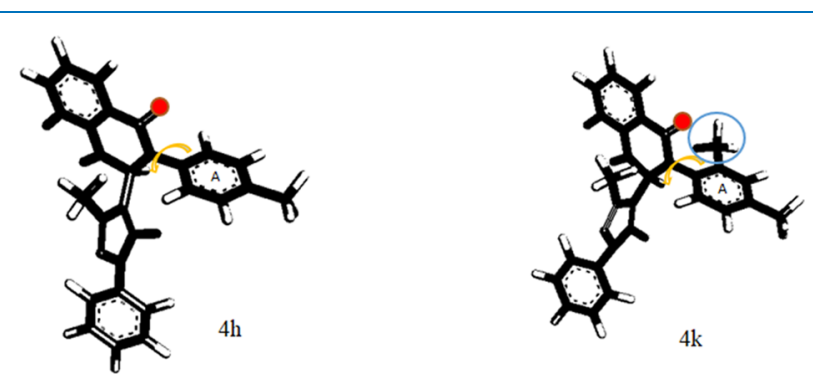

Figure 2. Comparison of the free rotation between molecules $4 \mathrm{~h}$ and $4 k$.

This is due to the steric congestion of methyl in the ortho position and its inhibition rather than that of the carbonyl group. Consistent with the result of Ichikawa et al., it would appear that the ring $\mathrm{A}$ in compound $\mathbf{4 k}$ is fixed and its electron cloud belonging to the $\pi$ orbital of the aromatic ring can more easily overlap and stabilize the single electron of DPPH. ${ }^{50}$

It is a good approximation to think of the geometry of free radicals as a shallow pyramid, which allows for overlap of the half-filled $\mathrm{p}$ orbital with adjacent $\pi$ bonds. Also, the stereoelectronic effect is defined by the preferred mode of the approach of a radical as it bonds to the $\pi$-electron system of an alkene group. When comparing our results to Broggi et al., it must be pointed out that single electrons can overlap with the adjacent $p$ orbitals as shown in Figure $3 .^{51}$ To prove this, molecules $4 \mathbf{k}$ and $4 \mathbf{l}$ were compared. Comparison between ligands showed that ligand 41 exhibits lower inhibition percentage due to its more free rotation.

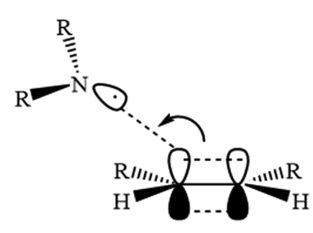

Intermolecular interaction

Figure 3. Intermolecular interaction between single electrons with the adjacent $\mathrm{p}$ orbitals.

Free radicals are stabilized by adjacent groups with lone pairs. Nitrogen, oxygen, and some halogens have lone pairs of electrons and can donate electron density to the half-empty $p$ orbital, which stabilizes the free radical system that is a hyperconjugation effect. This is an interaction between a halfempty orbital (the free radical) and a filled orbital (the lone pair of oxygen). Probably for this reason, the inhibitory percentage of molecule $4 \mathbf{i}$ is high.

The excess free radicals circulating in the body oxidize the low-density lipoproteins (LDL), making them potentially lethal; the excess free radicals can also accelerate aging processes and have been linked to other very serious pathologies, such as brain stroke, diabetes mellitus, rheumatoid arthritis, Parkinson's disease, Alzheimer's disease, and cancer. ${ }^{47,52}$ The essential features of oxidation via a free radical-mediated chain reaction are initiation, propagation, branching, and termination steps. ${ }^{53}$ The process may be initiated by the action of outside agents such as heat, light, or ionizing radiation or by chemical initiation involving metal ions or metalloproteins. There is great attention in antioxidants, predominantly in those planned to prevent the presumed harmful properties of free radicals in the human body as well as the deterioration of fats and other ingredients of foodstuffs. 53

Compound $4 \mathbf{j}$ was found to be an excellent antioxidant agent. It is an appropriate candidate for further development as antioxidants. Further studies are required to determine whether compound $\mathbf{4 j}$ could be a potential treatment for some notable diseases caused by oxidative stress, such as neural disorders, lung diseases, cancer, heart disease, and diabetes.

Studies on the antioxidant effects of similar compounds are limited. According to Tong et al., acortatarins A, one of the two novel alkaloids with a naturally unusual morpholine motif isolated from the rhizome of Acorus tatarinowii, could significantly inhibit reactive oxygen species production in high-glucose-stimulated mesangial cells in a dose- and timedependent manner. ${ }^{54}$ Similarly, Chiou et al. have shown that the synthetic compound magnolamide from pyrrole-2,5-dicarbaldehyde definitely inhibited $\mathrm{CuSO}_{4}$-induced oxidation of human LDL $\left(\mathrm{IC}_{50}=9.7 \mu \mathrm{M}\right)$, with similar activity to the antioxidant standards probucol and resveratrol. ${ }^{55}$

Hematological Study in Vivo. A summary of significant changes in the levels of some hematological parameters in mice blood samples, comprising the red blood cells (RBC), white blood cells (WBC), hemoglobin concentration $(\mathrm{Hb})$, mean corpuscular volume (MCV), mean corpuscular hemoglobin $(\mathrm{MCH})$, mean corpuscular hemoglobin concentration (MCHC), hematocrit (HCT), platelet (PLT), red cell distribution width (RDW), albumin (ALB), creatinine $(\mathrm{Cr})$, triglyceride (TG), cholesterol (CLST), and glucose (GLU), separately after intraperitoneal administration of two 0.3 and 0.5 $\mathrm{mM}$ doses of three quinazoline derivatives (4h, $4 \mathbf{j}$, and $4 \mathbf{k}$ ), compared with the negative (normal) and positive control (diabetic) groups is shown in Table 4.

At one glance, the measurable changes in hematological parameter values were observed compared to their control groups (Table 4).

According to Lawal et al., the erythrocyte parameters comprising the $\mathrm{RBC}, \mathrm{Hb}, \mathrm{MCH}, \mathrm{MCHC}$, and $\mathrm{RDW}$ are appropriate indicators of the circulatory erythrocyte levels and offer the valuable indexes of the bone marrow capacity to produce the RBC following the administration of drugs, toxins, or plant extracts. ${ }^{56}$ In line with the ideas of Mishra and Tandon, it can be revealed that a significant increase in $\mathrm{Hb}(\mathbf{4 j}), \mathrm{RBC}(\mathbf{4 h}$ and $4 \mathbf{j}$ ), and MCHC ( $\mathbf{4 h}$ and $\mathbf{4 k}$ ) following treatment with two 0.3 and $0.5 \mathrm{mM}$ doses of quinazoline derivatives may indicate the stimulation of erythropoiesis by these chemicals. ${ }^{57}$

According to the results, a dramatically significant increase was observed in the serum cholesterol and TG levels between the diabetic and the normal groups $(p<0.5)$. These factors were remarkably improved dose-dependently after administration of two doses of all quinazoline derivatives compared to the diabetic group $(p<0.05)$. However, the compound 4 h has shown more reducing effects on cholesterol and TG concentrations $(p<$ $0.05)$. This may be due to steric effect and the smaller size of this molecule than other molecules, which makes it more reactive. These molecules certainly have the potential to be developed as antihyperlipemic compounds.

Hyperlipidemia is the presence of high levels of lipids in the blood. It is a metabolic derangement caused by many diseases, especially cardiovascular diseases. ${ }^{58}$ There are many classes of lipid-lowering agents. All these drugs have different mechanisms 
Table 4. Significant Changes, in Some Hematological Parameters and Electrolyte Levels (Mean \pm SD), of Mice Blood Samples, after Administration of Two 0.3 and $0.5 \mathrm{mM}$ Doses of Quinazolinone Derivatives Compared with Control Groups

\begin{tabular}{|c|c|c|c|c|c|c|c|c|}
\hline \multirow[b]{3}{*}{ parameters } & \multicolumn{6}{|c|}{ compound } & \multirow[b]{3}{*}{ diabetic control } & \multirow[b]{3}{*}{ normal control } \\
\hline & \multicolumn{2}{|c|}{$4 \mathrm{~h}$} & \multicolumn{2}{|c|}{$4 j$} & \multicolumn{2}{|c|}{$4 k$} & & \\
\hline & 0.3 & 0.5 & 0.3 & 0.5 & 0.3 & 0.5 & & \\
\hline $\operatorname{WBC}\left(10^{3} / \mathrm{mm}^{3}\right)$ & 5.3 & 5.6 & 7.6 & 8 & 3.15 & 2.8 & 8.3 & 5.6 \\
\hline $\operatorname{RBC}\left(10^{6} / \mathrm{mm}^{3}\right)$ & 9.05 & 9.92 & 9.34 & 9.17 & 8.05 & 7.92 & 8.74 & 9.18 \\
\hline $\mathrm{HB}(\mathrm{g} / \mathrm{dl})$ & $14.5 \pm 0.1$ & $14.2 \pm 0.25$ & $14.8 \pm 0.34$ & $14.8 \pm 0.3$ & $8.0 \pm 0.2$ & $10.9 \pm 0.1$ & $13.3 \pm 0.2$ & $14.5 \pm 0.2$ \\
\hline $\operatorname{HCT}(\%)$ & $37.1 \pm 0.1$ & $37.9 \pm 0.1$ & $38.6 \pm 0.1$ & $39.6 \pm 0.08$ & $18.1 \pm 0.1$ & $34.9 \pm 0.2$ & $38.5 \pm 0.1$ & $37.3 \pm 0.1$ \\
\hline $\operatorname{MCV}\left(\mu \mathrm{m}^{3}\right)$ & 40.9 & 40.1 & 40.2 & 39.9 & 44.9 & 44.1 & 44.1 & 40.6 \\
\hline $\mathrm{MCH}(\rho \mathrm{g})$ & $15.8 \pm 0.1$ & $15.5 \pm 0.23$ & $15.7 \pm 0.2$ & $15.5 \pm 0.03$ & $15.8 \pm 0.1$ & $15.8 \pm 0.1$ & $15.3 \pm 0.1$ & $15.8 \pm 0.07$ \\
\hline $\mathrm{MCHC}(\mathrm{g} / \mathrm{dL})$ & $44.0 \pm 0.2$ & $41.2 \pm 0.1$ & $38.6 \pm 0.2$ & $38.2 \pm 0.1$ & $44.0 \pm 0.2$ & $41.2 \pm 0.2$ & $34.7 \pm 0.1$ & $38.9 \pm 0.1$ \\
\hline $\operatorname{PLT}\left(10^{3} / \mathrm{mm}^{3}\right)$ & 5884 & 10000 & 1350 & 1326 & 5884 & 10000 & 1072 & 1336 \\
\hline RDW (\%) & $21.8 \pm 0.03$ & $23.6 \pm 0.02$ & $22.5 \pm 0.01$ & $22.2 \pm 0.02$ & $12.2 \pm 0.01$ & $24.8 \pm 0.01$ & $24.3 \pm 0.02$ & $22.2 \pm 0.01$ \\
\hline Alb (g/dL) & $2.7 \pm 0.04$ & $2.7 \pm 0.02$ & $2.9 \pm 0.02$ & $2.8 \pm 0.01$ & $2.8 \pm 0.07$ & $2.8 \pm 0.03$ & $3.3 \pm 0.03$ & $2.8 \pm 0.03$ \\
\hline $\mathrm{UA}(\mu \mathrm{M})$ & $61 \pm 3$ & $62 \pm 1.5$ & $65 \pm 2$ & $65 \pm 2$ & $66 \pm 2.7$ & $67 \pm 3.3$ & $71.9 \pm 2.7$ & $64 \pm 3.2$ \\
\hline Chlst (mg/dL) & $64 \pm 3.2$ & $58 \pm 6$ & $66 \pm 1.4$ & $62 \pm 2.8$ & $64 \pm 3.2$ & $60 \pm 6$ & $79 \pm 2.4$ & $73 \pm 5$ \\
\hline TG (mg/dL) & $127 \pm 1.5$ & $109 \pm 0.7$ & $123 \pm 3$ & $116 \pm 3$ & $127 \pm 2.5$ & $121 \pm 4$ & $191.2 \pm 5.2$ & $131 \pm 4.2$ \\
\hline $\mathrm{Cr}(\mathrm{mg} / \mathrm{dL})$ & $0.41 \pm 0.05$ & $0.4 \pm 0.05$ & $0.41 \pm 0.07$ & $0.41 \pm 0.09$ & $0.45 \pm 0.05$ & $0.42 \pm 0.05$ & $0.85 \pm 0.03$ & $0.45 \pm 0.02$ \\
\hline
\end{tabular}

of action. However, these lipid-lowering drugs possess various side effects. Hence, research is continuing to discover novel agents that are more potent and safe. ${ }^{59}$ The quinazolinone derivatives are found to have various biological activities, including anti-hyperlipidemic activities. ${ }^{58,59}$

Kurogi et al. showed that the quinazolines and $4(3 \mathrm{H})$ quinazolinones are hypolipidemic agents. They have reduced the triglyceride and total cholesterol levels. ${ }^{60}$ According to Kusunoki et al., the lipoprotein lipase (LPL) activator NO-1886 (ibrolipim) shows antiobesity effects in high-fat-induced obese rats. ${ }^{61}$ This quinazoline derivative decreased the levels of plasma triglycerides, nonesterified free fatty acids, and glucose as well as the enhancement of LPL activity in animal skeletal muscle. ${ }^{61}$ Promising results obtained from the subchronic study of Refaie et al. ${ }^{62}$ revealed the antihyperlipidemic effect of quinazolinone compounds by inhibition of dietary cholesterol absorption and/ or intestinal human acyl-CoA: cholesterol acyltransferase (ACAT) activity. The significant reductions in serum total cholesterol, triacylglycerol levels, and cholesterol ester were observed in their study. ${ }^{61}$ Similarly, a decrease in serum cholesterol and TG levels of some synthetic novel quinazoline derivatives, as well as significantly increased in the serum HDL level has shown by Kathiravan et al. ${ }^{63}$

Moreover, it was found that all verified compounds showed a significant decrease in creatinine level as compared with the diabetic control group $(p<0.05)$.

According to very recent studies, the most important lipidlowering drugs have even caused diabetes mellitus disease. ${ }^{37,64} \mathrm{~A}$ meta-analysis study by Wang et al. showed that statin therapy and the relative reduction in LDL are associated with a risk of new-onset diabetes. ${ }^{38}$ Previously, Simonen et al. have demonstrated that diabetes is evidently associated with high cholesterol synthesis and mild elevated serum and lipoprotein triglyceride levels. ${ }^{65}$ They have verified that the insulin-resistant fat cells release the extensive free fatty acids to the circulation. In their study, lipoprotein synthesis had also increased. Their findings showed a direct association between blood sugar levels and cholesterol synthesis. ${ }^{65}$ Therefore, the offering of such drugs with potentially concurrent beneficial effects on both diseases in the future of drug discovery is really promising.

Administration of a derivative $(\mathbf{4} \mathbf{j})$ resulted in higher levels of $\mathrm{WBC}$ in these treated groups compared to the nondiabetic control group $(p<0.05)$, but not more than the diabetic control group, while it was significantly reduced in diabetic mice that received the compound $\mathbf{4 k}$ compared to the control groups at two levels of concentrations. All molecules had significant differences with normal and diabetic groups $(p<0.05)$. This did not include the molecule $4 \mathrm{~h}$ at a concentration of $0.5 \mu \mathrm{M}$ compared to the normal control group.

The highest mean RBC level was observed in the presence of the compound $\mathbf{4 h}$, compared to the other molecules and both control groups $(p<0.05)$. In this parameter, all desired molecules in both concentrations had a significant difference compared to the diabetic group. This result ties well with previous studies that reported the significant increase in response to the administration of chemicals. ${ }^{56,57}$

However, the molecule $4 \mathbf{k}$ had a significant difference compared to the normal group. Then, the influence of the 2,4di-Me substituents in the molecule $4 \mathbf{k}$ could be remarkable.

From the perspective of the association between antioxidant and hematological effects, the study of Kelkar et al. ${ }^{46}$ revealed that antioxidants can combat oxidative stress and improve the hematological status such as $\mathrm{Hb}$ and $\mathrm{RBC}$ levels. Others have shown that the chemicals with antioxidant activities can improve the hematological parameters. ${ }^{66,67}$

The deleterious effects of diabetes mellitus on hematological parameters were also reported by Oyedemi et al.. ${ }^{68}$

Serum creatinine level is the most common index of renal function. As indicated, administering the desired compounds significantly decreased the creatinine levels compared to the diabetic groups in the animal model. In line with the finding of Tsompos et al., we speculate that our antioxidant agents may improve renal function by increasing creatinine excretion. ${ }^{69}$ The effects of antioxidants on the creatinine level were in accordance with the results of Dennis and Witting. ${ }^{70}$ Hence, introducing a novel uncomplicated drug with the revealed effects can be a great aid for these patients.

The HCT (in $0.3 \mathrm{mM}$ ) and $\mathrm{Hb}$ levels were decreased significantly alone in the group that received the compound $4 \mathbf{k}$. Except for the molecule $4 \mathbf{j}$, at a dose of $0.5 \mu \mathrm{M}$, all confirmed molecules had significant differences compared to the diabetic group $(p<0.05)$. No statistically significant changes were observed in the HCT levels in the mice exposed to the compound $4 \mathbf{j}$ at a dose of $0.3 \mu \mathrm{M}$ compared to the normal group. 
Table 5. Mean Blood Glucose Levels (in $\mathrm{mM}$ ) in Diabetic Mice Treated with Quinazoline Derivatives $(4 \mathrm{~g}-4 \mathrm{l})$

\begin{tabular}{|c|c|c|c|c|c|c|c|c|}
\hline \multirow[b]{2}{*}{ conc. (mM) } & \multicolumn{6}{|c|}{ compound } & \multirow[b]{2}{*}{ diabetic control } & \multirow[b]{2}{*}{ normal control } \\
\hline & $4 g$ & $4 \mathrm{~h}$ & $4 i$ & $4 j$ & $4 k$ & 41 & & \\
\hline 0.3 & $65 \pm 2$ & $44 \pm 1$ & $44 \pm 1$ & $<\mathrm{LOQ}^{a}$ & $29 \pm 1$ & $<$ LOQ & $365 \pm 4$ & $70 \pm 2$ \\
\hline 0.5 & $27 \pm 1$ & $22 \pm 1$ & $<$ LOQ & $<\mathrm{LOQ}$ & $<$ LOQ & $<$ LOQ & $524 \pm 6$ & $57 \pm 2$ \\
\hline
\end{tabular}

The significant increases were observed in the MCHC and PLT levels in groups that received $4 \mathbf{k}$ and $4 \mathrm{~h}$ compounds compared to the diabetic group $(p<0.05)$.

A number of chemicals and natural products have been scientifically tested and reported possessing the ability to decrease blood glucose levels of normal and/or diabetic animals. $^{61-74}$

The mean blood glucose concentrations were determined to be $70 \pm 2$ and $57 \pm 2(\mathrm{mM})$ in the control group in doses of 0.3 and $0.5 \mathrm{mM}$ and $365 \pm 4$ and $524 \pm 6$ in the diabetic group, respectively. Table 5 shows that treatment of diabetic mice with six quinazoline derivatives $(\mathbf{4 g}-\mathbf{4 l})$ caused a significant and dose-dependent reduction in blood sugar levels compared to both control groups $(p<0.05)$.

Administration of both doses of compounds $4 \mathbf{j}$ and $\mathbf{4 1}$ resulted in a significant collapse in blood glucose levels as much as below the limit of quantification of the method ( $\mathrm{LOQ}=20 \mathrm{mM})$. Such a reduction was also perceived in compound $4 \mathbf{k}$ at a dose of 0.5 $\mathrm{mM}$. These tested compounds were found to be uniquely reducing sugar levels.

As a whole, our hematological study revealed that the quinazoline derivatives are safe from the viewpoint of hematotoxicity and can even recover the hematological side effects associated with diabetes mellitus.

$\alpha$-Glucosidase Inhibitory Activity. $\alpha$-Glucosidase is a catabolic enzyme that regulates the body's plasma glucose levels by providing energy sources to maintain healthy functioning. $\alpha$ Glucosidase inhibitor drugs reduce the glucose level of blood as a strategy for the treatment of type 2 diabetes. ${ }^{75}$

All the synthesized compounds showed the potent inhibitory potential ranging from $(2.6 \pm 0.1,2.5 \pm 0.1 \mu \mathrm{M})$ to $(29.3 \pm 0.5$, $25.4 \pm 0.6 \mu \mathrm{M})$ in 0.3 and $0.5 \mathrm{mM}$ of samples, respectively, compared to acarbose as a standard with $\mathrm{IC}_{50}=34.4 \pm 0.3$ and $30.1 \pm 0.2 \mu \mathrm{M}$. The $\mathrm{IC}_{50}$ levels in all the test compounds decreased compared to that of the standard drug $(p<0.05)$. Also, as shown in Table 6, the $\mathrm{IC}_{50}$ values in both concentrations of the samples ( 0.3 and $0.5 \mathrm{mM}$ ) were dose-dependently decreased in all tests and standard compounds. Amongst all the synthesized compounds, the derivatives $\mathbf{4 h}, \mathbf{4 i}$, and $\mathbf{4 l}$ showed the strongest enzyme inhibitory potential than the standard drug acarbose.

Table 6. $\alpha$-Glucosidase Inhibition of Quinazoline Derivatives (4g-4l) Compared with Acarbose as a Standard

\begin{tabular}{lcc} 
& \multicolumn{2}{c}{$\mathrm{IC}_{50}(\mu \mathrm{M})$} \\
\cline { 2 - 3 } no. & conc. $(0.3 \mathrm{mM})$ & conc. $(0.5 \mathrm{mM})$ \\
$\mathbf{4 g}$ & $29.3 \pm 0.5$ & $25.4 \pm 0.6$ \\
$\mathbf{4 h}$ & $2.6 \pm 0.1$ & $2.5 \pm 0.1$ \\
$\mathbf{i}$ & $2.96 \pm 0.8$ & $2.62 \pm 0.5$ \\
$\mathbf{4 j}$ & $15.9 \pm 0.3$ & $11.7 \pm 0.3$ \\
$\mathbf{4 k}$ & $21.5 \pm 0.4$ & $18.2 \pm 0.2$ \\
$\mathbf{4 l}$ & $3.03 \pm 0.5$ & $3.0 \pm 0.1$ \\
acarbose & $34.7 \pm 0.3$ & $30.1 \pm 0.2$
\end{tabular}

In a series of recent studies, some quinazoline derivatives were reported as extremely active $\alpha$-glucosidase inhibitors for controlling hyperglycemia. ${ }^{76-78}$ In the study of Gurram et al., a series of 21 synthesized novel quinazoline derivatives have been screened against $\alpha$-glucosidase. ${ }^{76}$ Among all the tested molecules, seven compounds showed $<20 \mu \mathrm{M}$ activity to $\alpha$ glucosidase, and six compounds showed exhibited excellent inhibition activities when compared to acarbose $(6.2 \mu \mathrm{M})$, with the $\mathrm{IC}_{50}$ values between 3.2 and $8.6 \mu \mathrm{M}^{76}$ These results are comparable to our study results.

These findings are also consistent with the research study of Babar et al., showing that a synthetic quinazoline compound has a potent inhibitory effect toward $\alpha$-glucosidase with an $\mathrm{IC}_{50}$ value of $150.4 \pm 1.9 \mu \mathrm{M}$ compared to acarbose (336.9 \pm 9.0 $\mu \mathrm{M})$ as the standard. ${ }^{79}$ This is consistent with what has been found in the previous study of Garlapati et al.. ${ }^{80}$ They investigated the 25 synthesized quinazoline compounds to biological assays against $\alpha$-glucosidase and found that three compounds were potentially active as $\alpha$-glucosidase inhibitors and showed activity with $\mathrm{IC}_{50}$ values of $<10 \mu \mathrm{M}$. They have demonstrated that these main compounds are excellent candidates for further pharmacological applications.

Docking Study. To find the correlation between the experimental and computational data, the docking study of the compounds was performed against $\alpha$-glucosidase enzyme inhibitory activities. According to the binding site in $\alpha$ glucosidase, the desired compound would be able to form the different types of molecular bonds with the $\alpha$-glucosidase structure and making it a favorable binding site. The estimated binding energies $(\mathrm{kcal} / \mathrm{mol})$ of the 10 clusters are presented in Table 7.

Among the 10 clusters, the preeminent results for each molecule from the perspective of their binding energies (kcal/ $\mathrm{mol}), \mathrm{Ki}(\mu \mathrm{M})$, and other conformation information were selected for further examinations (Table 8).

Our docking results showed that all compounds have more stability than acarbose as the control group (Table 8). The best conformations from the docking procedure with the best-scored pose and the lowest binding energy (about -6.1 to $-8.85 \mathrm{kcal} /$ $\mathrm{mol}$ ) were selected for these ligands $(\mathbf{4 g}-4 \mathrm{l})$. From the docking results, compound $4 \mathbf{i}$ with the $\mathrm{OH}$ substituent at the para position exhibited the least binding energy with $\alpha$-glucosidase that shows the overcoming of hydrogen bonding rather than other polar effects in these compounds. Table 9 shows the number of different types of molecular bonds between ligands and the $\alpha$-glucosidase.

At this stage of understanding, it can be construed that the high binding affinity of compounds $\mathbf{4 i}$ and $\mathbf{4 1}$ is related to the greater number of the van der Waals and hydrogen bond between the enzyme and ligand (Figure 4). According to Table 9, $\pi$-anion, $\pi-$ cation, and $\pi-\pi$ interactions are less important. We speculate that the low affinity of the molecule $4 \mathbf{j}$ with the enzyme may be due to the steric effect of chlorine than other substitutions in the para position. Furthermore, the electronwithdrawing (EWG) and the electron-donating groups (EDG) 
Table 7. Binding Energies of the Compounds Based on Their Clusters ( $\mathrm{kcal} / \mathrm{mol}$ )

\begin{tabular}{|c|c|c|c|c|c|c|c|c|c|c|}
\hline \multirow[b]{2}{*}{ compound } & \multicolumn{10}{|c|}{ binding energy ( $\mathrm{kcal} / \mathrm{mol})$} \\
\hline & 1 & 2 & 3 & 4 & 5 & 6 & 7 & 8 & 9 & 10 \\
\hline $4 g$ & -8.02 & -8.36 & -7.75 & -7.75 & -6.71 & -7.77 & -7.93 & -7.31 & -6.41 & -6.37 \\
\hline $4 h$ & -6.92 & -6.90 & -6.87 & -6.31 & -6.11 & -5.91 & -5.83 & -5.83 & -5.81 & -4.87 \\
\hline $4 \mathrm{i}$ & -8.85 & -8.83 & -8.8 & -8.64 & -8.46 & -8.42 & -8.02 & -7.85 & -6.03 & -6.02 \\
\hline $4 \mathbf{j}$ & -6.32 & -6.22 & -6.15 & -6.04 & -6.05 & -5.77 & -5.77 & -5.18 & -5.18 & -5.11 \\
\hline $4 k$ & -6.10 & -6.07 & -5.96 & -5.94 & -5.89 & -5.83 & -5.67 & -5.67 & -5.41 & -4.79 \\
\hline 41 & -6.46 & -6.46 & -8.25 & -6.73 & -7.14 & -6.88 & -7.83 & -7.49 & -7.79 & -7.29 \\
\hline
\end{tabular}

Table 8. Docking Results of Synthesized Compounds against $\alpha$-Glucosidase

\begin{tabular}{|c|c|c|c|c|c|c|c|}
\hline compound & $\mathrm{Ki}(\mu \mathrm{M})$ & binding energy $(\mathrm{kcal} / \mathrm{mol})$ & ligand efficiency & intermolecular energy & torsional energy & electrostatic energy & unbound energy \\
\hline $4 g$ & 2.66 & -7.61 & -0.25 & -8.2 & 0.6 & 0.03 & -1.64 \\
\hline $4 \mathrm{~h}$ & 8.43 & -6.92 & -0.22 & -7.52 & 0.6 & 0.03 & -1.72 \\
\hline $4 i$ & 0.326 & -8.85 & -0.29 & -9.74 & 0.89 & 0.0 & -1.59 \\
\hline $4 j$ & 23.39 & -6.32 & -0.2 & -6.91 & 0.6 & 0.02 & -1.62 \\
\hline $4 k$ & 33.82 & -6.10 & -0.19 & -6.7 & 0.6 & 0.08 & -1.33 \\
\hline 41 & 0.903 & -8.25 & -0.26 & -8.84 & 0.6 & -0.11 & -1.46 \\
\hline acarbose & & 0.67 & 0.02 & -5.89 & 6.56 & -0.73 & -11.41 \\
\hline
\end{tabular}

Table 9. Number of Different Types of Molecular Bonds between Ligands and the $\alpha$-Glucosidase

\begin{tabular}{lccccc} 
compound & $\begin{array}{c}\text { hydrogen } \\
\text { bonding }\end{array}$ & $\begin{array}{c}\text { van der } \\
\text { Waals }\end{array}$ & $\begin{array}{c}\pi \text {-anion and } \pi- \\
\text { cation }\end{array}$ & $\begin{array}{c}\pi-\pi \\
\text { alkyl }\end{array}$ \\
$\mathbf{4 g}$ & & 10 & 3 & 2 & 6 \\
$\mathbf{4 h}$ & & 7 & 4 & 3 & 4 \\
$\mathbf{4 i}$ & 1 & 13 & 2 & 1 & 7 \\
$\mathbf{4 j}$ & & 12 & & 2 & 6 \\
$\mathbf{4 k}$ & & 10 & 1 & 2 & 5 \\
$\mathbf{4 l}$ & 3 & 11 & & 3 & 3 \\
acarbose & 2 & & & & 1 \\
\hline
\end{tabular}

had almost similar effects $(4 \mathrm{i}>4 \mathrm{l}>4 \mathrm{~g}>4 \mathrm{~h}>4 \mathbf{j}>4 \mathrm{k}>$ acarbose). The higher energy in acarbose may be due to the absence of $\pi$ interactions in its structure (Figure 4).

The involved residues in the close interaction are listed in Table 10.

When comparing the results of Figure 4, it must be pointed out that the molecules $\mathbf{4 i}$ and $\mathbf{4 l}$ with the single substituent in the para position had the highest number of amino acid residues $(20$ amino acids). Also, the number of amino acids in $4 \mathbf{h}, 4 \mathbf{k}$, and acarbose is the same. Generally, the number of residues increases from $4 \mathrm{~h}$ to $4 \mathrm{l}$ ( $4 \mathrm{i}$ and $4 \mathrm{l}>\mathbf{4 g}>\mathbf{4 j}>\mathbf{4 h}, \mathbf{4 k}$, and acarbose).

The comparison between the amino acid residues of the molecules and acarbose showed that the highest share of amino acids was related to the compound $\mathbf{4 g}$ with 13 amine acids (Phe144, Phe163, Tyr63, Asp326, His103, Asn324, Phe282, Asn258, Ala200, Asp199, Val100, Glu256, and Arg197). Phe163, Asn258, Asp199, Glu256, and Ala200 were common in all compounds similar to acarbose, where the two amino acids Arg411 and Leu258 found in acarbose have not existed in any of the relevant molecules.

\section{CONCLUSIONS}

In conclusion, the quinazoline derivatives from pyrrole-2carbaldehyde and amines, particularly molecules $4 \mathbf{i}$ and 41 , were a potent and amazing anti- $\alpha$-glucosidase agent with strong binding to enzyme that correlated well with the experimental data. There was a good association between in vitro and in silico studies. The hematological study of the desired compounds revealed that the quinazoline derivatives are safe from the viewpoint of hematotoxicity and seem to improve the hematological abnormalities associated with diabetes mellitus in the animal model. In addition, these findings provide additional information about the molecule $4 \mathrm{~h}$ that certainly has the potential to be developed as antihyperlipemic drugs because of its excellent reducing effects on cholesterol and TG levels. The majority of compounds, particularly the compound $\mathbf{4 j}$, presented the exceptional radical scavenging. This conclusion follows from the fact that the antioxidant agents improved the hematological parameters. This is desirable for future work after the safety evaluation of the compounds.

\section{EXPERIMENTAL SECTION}

Materials and Methods. General. All chemicals were purchased from the Fluka, Merck, and Aldrich chemical companies. All products were characterized by comparison of their FT-IR (Fourier transform infrared), ${ }^{1} \mathrm{H} \mathrm{NMR}$, and ${ }^{13} \mathrm{C}$ NMR spectroscopic data.

The study was permitted by the Medical Ethics Committee of Bushehr University of Medical Sciences and Health Services, Bushehr-Iran, and a written informed consent was obtained from all subjects of study. All animal works were carried out in accordance with the National Ethical Guidelines for Animal Research in Iran (2005) under a project license, which was approved by the Animal Care and Use Committee of the Persian Gulf, according to the protocol PG/FS/CHDO2. All animals were kept in a climate-controlled environment at $25^{\circ} \mathrm{C}$ on a $12 \mathrm{~h}$ light $/ 12 \mathrm{~h}$ dark cycle. Adequate food and water were available during all experimental processes, and all efforts were made to minimize suffering.

1-Aryl-5-chloro-3-methyl-1H-pyrazole-4-carbaldehyde General Preparation. First, $64 \mathrm{~mL}$ of phosphoryl chloride $(0.7$ $\mathrm{M})$ was added dropwise to $23 \mathrm{~mL}$ of ice-cold dimethylformamide $(0.3 \mathrm{M})$. After adding $17.5 \mathrm{~g}$ of 3-methyl-1-phenyl-5pyrazolone $(0.1 \mathrm{M})$, the mixture was heated under reflux conditions for $1 \mathrm{~h}$. At room temperature, a volume of $600 \mathrm{~mL}$ of cold water was added to the mixture and filtered and then recrystallized from ethanol.

2,3-Dihydroquinazolin-4(1H)-ones General Synthesis Method. To a mixture of isatoic anhydride (1 mmol), 5- 

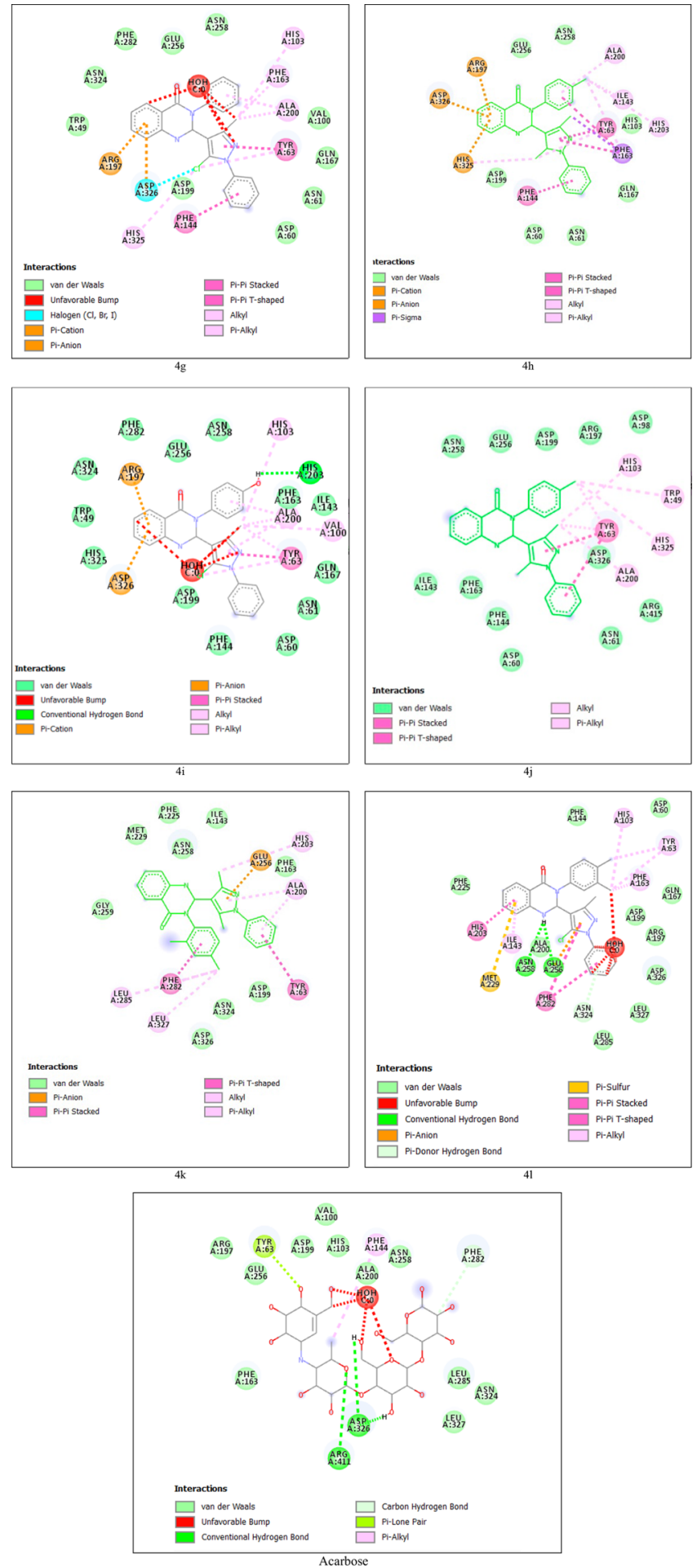

Figure 4. Docking of the six synthesized compounds $(4 \mathrm{~g}-4 \mathrm{l})$ and acarbose (as the standard molecule) with $\alpha$-glucosidase enzyme.

chloro-3-methyl-1-phenyl-1H-pyrazole-4-carbaldehyde (3) (1 $\mathrm{mmol}$ ), and aniline derivatives ( $1 \mathrm{mmol}$ ) in $5 \mathrm{~mL}$ of ethanol was added to $0.027 \mathrm{~g}$ of $\mathrm{Al}_{2}\left(\mathrm{SO}_{4}\right)_{3} \cdot 6 \mathrm{H}_{2} \mathrm{O}$ and heated under reflux conditions. The reaction progress was monitored by thin-layer chromatography (TLC). After completing the reaction, the solvent was removed. The mixture was cooled to precipitate the corresponding pyrazol-quinazolinone products, which were finally purified by column chromatography on silica gel using $n$-hexane/ethyl acetate as an eluent.
Antioxidant Activity. The antioxidant activities (AA \%) of the products were performed by the free radical DPPH $(1,1-$ diphenyl-2-picrylhydrazyl; Fluka, Buchs, Switzerland) according to the Buritz and Bucar method. ${ }^{81}$ Dispersing delocalized electrons all over the molecule makes DPPH a free stable radical. The delocalized electron causes a deep purple color at $\lambda_{\max }=517$ $\mathrm{nm}$. When a solution of DPPH is mixed with a substrate acting as a hydrogen atom donor, a stable, nonradical form of DPPH is obtained with a simultaneous change in color from violet to pale yellow. Briefly, $50 \mathrm{~mL}$ from each of the methanolic solutions $(4 \mathbf{h}, 4 \mathbf{j}$, and $4 \mathbf{k})$, in different dilutions of $0.2,0.4,0.6,0.8$, and 1.0 $\mu \mathrm{g} / \mathrm{mL}$, was mixed with $5 \mathrm{~mL}$ of the DPPH methanolic solution $(0.004 \%)$. The DPPH solution was kept in a dark place. After 30 min incubation, the absorbances of the samples were measured using a Cecil Aquarius CE7200 double-beam spectrophotometer (Cecil, England) at $517 \mathrm{~nm}$. The methanolic solutions of six compounds and DPPH were used as blank and control samples, respectively. Inhibition (I) of the DPPH radical in percent (\%) was calculated by the following equation

$$
I(\%)=\left(A_{\text {blank }}-A_{\text {sample }}\right) / A_{\text {blank }} \times 100
$$

where $A_{\text {blank }}$ is the absorbance at $517 \mathrm{~nm}$ after a period of $30 \mathrm{~min}$ without the addition of the antioxidant and $A_{\text {sample }}$ is the absorbance in the presence of the antioxidant.

An Inhibition value versus different concentrations diagram was used to calculate $\mathrm{IC}_{50}$. Results are expressed as the antioxidant amount that reduces the DPPH concentration to $50 \%$ of the initial value. ${ }^{82}$ All measurements were repeated three times.

Hematological Study In Vivo. For some hematological studies in vivo of the compounds $(\mathbf{4 h}, \mathbf{4 j}$, and $\mathbf{4 k})$, including the blood glucose levels, 40 male mice (weighing approximately 20 $\pm 2 \mathrm{~g}$ ) from the animal house of the Bushehr University of Medical Sciences, Bushehr-Iran, were randomly divided into eight groups $(n=5)$. After fasting for $18 \mathrm{~h}$, the experimental diabetes was induced by intraperitoneal (ip) injection of $0.5 \mathrm{~mL}$ of a single dose of $50 \mathrm{mg} / \mathrm{kg}$ aloxan. After 5 days of the aloxan injection, for monitoring of glucose, the blood tail was measured using a glucometer (Bionime Rightest GM 300, Switzerland), and animals with a blood glucose value of over $200 \mathrm{mg} / \mathrm{dL}$ were assumed to be diabetic. ${ }^{83}$ Furthermore, animals were observed for general signs of diabetes like polydipsia, hyperphagia, and polyuria during the study. This group of animals was considered as a positive control group. Six groups of animals have separately received $0.5 \mathrm{~mL}$ of the compounds $(\mathbf{4 h}, \mathbf{4 j}$, and $\mathbf{4 k})$ at the doses of 10 and $20(\mathrm{mg} / \mathrm{kg}$, ip) for 1 week. Also, one group of animals was given saline as a negative control group. For hematological parameters in vivo, the animals were anesthetized with diethyl ether. A blood sample of each animal was collected by cardiac punctures into both EDTA (10\%) tubes for directly hematological tests and without anticoagulant tubes for biochemical examinations. The performance evaluations of hematological parameters include $\mathrm{RBC}, \mathrm{WBC}, \mathrm{Hb}, \mathrm{MCV}$, $\mathrm{MCH}, \mathrm{MCHC}$, PLT, RDW, and HCT and were performed using the Sysmex XE-5000 hematology analyzer. All tests were done in triplicate, and the data were expressed as mean \pm SD. Statistical analysis was carried out using the Kruskal-Wallis test. $p<0.05$ was considered statistically significant. For chemical analysis of serum electrolytes, a portion of free anticoagulant blood samples, which were previously described, were centrifuged at $600 \mathrm{~g}$ for $15 \mathrm{~min}$ and the supernatant was separated as the serum. Serum albumin, uric acid, glucose, triglyceride, and cholesterol were also measured. 
Table 10. Residues of the Synthesized Compounds and Acarbose in Docking Study with $\alpha$-Glucosidase Enzyme

\begin{tabular}{|c|c|c|}
\hline compound & $\begin{array}{l}\text { number of } \\
\text { residues }\end{array}$ & residues \\
\hline $4 \mathrm{~g}$ & 18 & $\begin{array}{l}\text { Trp49, Asn324, Phe282, Glu256, Asn258, His103, Phe163, Ala200, Val100, Tyr63, Gln167, Asn61, Asp60, Phe144, Asp199, Asp326, } \\
\text { Arg197, His325 }\end{array}$ \\
\hline 4h & 16 & Phe144, Ile143, Phe163, Gln167, Asp60, His103, His203, Asn61, Tyr63, Asp236, Ala200, Asn258, His325, Asp199, Glu256, Arg197 \\
\hline $4 \mathbf{i}$ & 20 & $\begin{array}{l}\text { His325, Trp49, Asp324, Phe282, Glu256, Arg197, Asn258, His103, His203, Phe163, Ile143, Ala200, Val100, Trp63, Glu167, Asn61, } \\
\text { Asp60, Phe 144, Asp199, Asp326 }\end{array}$ \\
\hline $4 \mathbf{j}$ & 17 & $\begin{array}{l}\text { Trp49, Arg197, Glu256, Asp98, Asp199, His325, Asp326, Arg415, Ala200, Asn61, Tyr63, His103, Ile143, Phe163, Phe144, Asn258, } \\
\text { Asp60 }\end{array}$ \\
\hline $4 \mathbf{k}$ & 16 & Gly259, Met229, Phe225, Asn258, Glu256, Phe282, His203, Leu285, Phe163, Asn324, Try63, Leu327, Asp326, Asp199, Ala200, Ile143 \\
\hline 41 & 20 & $\begin{array}{l}\text { Phe225, Phe144, His103, Asp60, Try63, Phe163, Glu167, Asp199, Arg197, Asp236, Leu327, Leu285, Asn324, Phe282, Glu256, Asn258, } \\
\text { Ala200, Ile143, Met229, His203 }\end{array}$ \\
\hline acarbose & 16 & Phe144, Phe163, Arg411, Tyr63, Asp326, Leu327, His103, Leu258, Asn324, phe282, Asn258, Ala200, Asp199, Val100, Glu256, Arg197 \\
\hline
\end{tabular}

$\alpha$-Glucosidase Inhibitory Activity. The $\alpha$-glucosidase inhibitory activities of the compounds were evaluated spectrophotometrically using a previously published method with some modifications. ${ }^{75}$ Briefly, for each compound, $20 \mu \mathrm{L}$ of $0.5 \mathrm{U} / \mathrm{mL}$ of $\alpha$-glucosidase solution was mixed with $120 \mu \mathrm{L}$ of $100 \mathrm{mM}$ potassium phosphate buffer $(\mathrm{pH}$ 6.9) and $10 \mu \mathrm{L}$ of the sample ( $0.3 \mathrm{mM}$, in buffer). Acarbose was used as a standard inhibitor. Each mixture was separately incubated at $37^{\circ} \mathrm{C}$ for 15 $\mathrm{min}$. The enzymatic reaction was initiated by adding $20 \mu \mathrm{L}$ of the substrate 4-nitrophenyl- $\alpha$-D-glucopyranoside (pNPG) (5 mM) in the buffer.

The mixture was repetitively incubated at $37^{\circ} \mathrm{C}$ for $15 \mathrm{~min}$. At that point, the reaction was stopped by adding $80 \mu \mathrm{L}$ of sodium carbonate solution $(0.2 \mathrm{M})$. The enzyme-free mixture was also used as a blank sample. Finally, the absorbance was measured at $405 \mathrm{~nm}$. The blank sample in which the substrate was changed with $50 \mu \mathrm{L}$ of the buffer was analyzed to accurately determine the background absorbance. The positive control sample (acarbose) was prepared to contain $10 \mu \mathrm{L}$ of DMSO (dimethyl sulfoxide) instead of test samples. The percentage of enzyme inhibition was calculated as $(1-B / A) \times 100$, where $A$ represents the absorbance of control without test samples and $B$ represents the absorbance in the presence of test samples. Analyses were carried out in triplicates, and the results were expressed as mean \pm SD.

Computational Details. The binding affinities between the identified structures (in addition to acarbose as the control compound) and the active site of the $\alpha$-glucosidase receptor were examined through docking studies using the AutoDock Tools 1.5.6 Workspace. ${ }^{84}$ Interactive visualization and analyses of the molecular structures were carried out in the Discovery Studio R2 64-bit Client system. The three-dimensional (3D) structure of $\alpha$-glucosidase was downloaded from the RCSB Protein Data Bank (PDB). The chemical structures of the ligands were obtained from the PubChem compound database. Open Babel was used to convert the PDB files to the PDBQT file. For docking analysis, PDB coordinates of the target proteins and ligands were optimized. Geometry optimization is performed using Gaussian 09 (adding missing residues). These coordinates had minimum energy and a stable conformation.

\section{ASSOCIATED CONTENT}

\section{S Supporting Information}

The Supporting Information is available free of charge on the ACS Publications website at DOI: 10.1021/acsomega.9b01906.

NMR, IR, and mass spectra for compounds $\mathbf{4 g - 4 l}$ (PDF)

\section{AUTHOR INFORMATION}

\section{Corresponding Author}

*E-mail: niknam@pgu.ac.ir.

ORCID $\odot$

Khodabakhsh Niknam: 0000-0001-5742-3846

\section{Funding}

This work was not funded by any agency.

Notes

The authors declare no competing financial interest.

\section{ACKNOWLEDGMENTS}

We are thankful to the Persian Gulf University Research Council for partial support of this work.

\section{REFERENCES}

(1) Kalyani, R. R.; Cannon, C. P.; Cherrington, A. L.; Coustan, D. R.; De Boer, I. H.; Feldman, H.; Fradkin, J.; Maahs, D.; Maryniuk, M.; Munshi, M. N.; Neumiller, J. J.; Umpierrez, G. E.; Das, S. R.; Kosiborod, M.; Berg, E. G.; Tamara, D.; Peterson, M. P.; Uelmen, S.; Cefalu, W. T. Professional Practice Committee: Standards of Medical Care in Diabetes-2018. Diabetes Care 2018, 41, S3.

(2) Javid, M. T.; Rahim, F.; Taha, M.; Rehman, H. U.; Nawaz, M.; Wadood, A.; Imran, S.; Uddin, I.; Mosaddik, A.; Khan, K. M. Synthesis, in vitro $\alpha$-glucosidase inhibitory potential and molecular docking study of thiadiazole analogs. Bioorg. Chem. 2018, 78, 201-209.

(3) Swaroopa, V.; Reddy, V.J. S.; Koshma, M.; Sudharani, Y.; Basha, S. J.; Adithya, T. N. Review on Antidiabetic Activity on Medicinal Plants. Int. J. Pharmacol. Res. 2017, 7, 230-235.

(4) Xu, X.; Wang, G.; Zhou, T.; Chen, L.; Chen, J.; Shen, X. Novel approaches to drug discovery for the treatment of type 2 diabetes. Expert Opin. Drug Discovery 2014, 9, 1047-1058.

(5) Prabhakar, P. K.; Doble, M. Mechanism of action of natural products used in the treatment of diabetes mellitus. Chin. J. Integr. Med 2011, 17, 563.

(6) Bell, D. S. H. Type 2 diabetes mellitus: what is the optimal treatment regimen? Am. J. Med. 2004, 116, 23-29.

(7) Rakesh, K. P.; Darshini, N.; Shubhavathi, T.; Mallesha, N. Biological Applications of Quinazolinone Analogues: A Review. Org. Med. Chem. 2017, 2, 555-585.

(8) Grei $\beta$, P. Ueber die Einwirkung des Cyans auf Anthranilsäure. Ber. Dtsch. Chem. Ges. 1869, 2, 415-418.

(9) Kacker, I. K.; Zaheer, S. Synthesis of Substituted 4-Quinazolones. J. Indian Chem. Soc. 1951, 28, 344-346.

(10) Jiang, S.; Zeng, Q.; Gettayacamin, M.; Tungtaeng, A.; Wannaying, S.; Lim, A.; Hansukjariya, P.; Okunji, C. O.; Zhu, S.; Fang, D. Antimalarial Activities and Therapeutic Properties of Febrifugine Analogs. Antimicrob. Agents Chemother. 2005, 49, 11691176.

(11) Jin, Y.; Zhou, Z.-Y.; Tian, W.; Yu, Q.; Long, Y.-Q. 4'-Alkoxyl substitution enhancing the anti-mitotic effect of $5-\left(3^{\prime}, 4^{\prime}, 5^{\prime}\right.$ - 
substituted)anilino-4-hydroxy-8-nitroquinazolines as a novel class of anti-microtubule agents. Bioorg. Med. Chem. Lett. 2006, 16, 5864-5869.

(12) Alagarsamy, V.; Murugesan, S.; Dhanabal, K.; Murugan, M.; de Clercq, E. AntiHIV, antibacterial and antifungal activities of some novel 2-methyl-3-(substituted methylamino)-(3H)-quinazolin-4-ones. Indian J. Pharm. Sci. 2007, 69, 304-307.

(13) Rakesh, K. P.; Ramesh, S.; kumar, H. M.; Chandan, S.; Gowda, D. C. Quinazolinones linked amino acids derivatives as a new class of promising antimicrobial, antioxidant and anti-inflammatory agents. Eur. J. Chem. 2015, 6, 254-260.

(14) Giri, R. S.; Thaker, H. M.; Giordano, T.; Williams, J.; Rogers, D.; Sudersanam, V.; Vasu, K. K. Design, synthesis and characterization of novel 2-(2,4-disubstituted-thiazole-5-yl)-3-aryl-3H-quinazoline-4-one derivatives as inhibitors of NF- $\kappa \mathrm{B}$ and AP- 1 mediated transcription activation and as potential anti-inflammatory agents. Eur. J. Med. Chem. 2009, 44, 2184-2189.

(15) Mosaad, S. M.; Mohammed, K. I.; Ahmed, M. A.; Abdel-Hamide, S. G. Synthesis of Certain New 6-Iodoquinazolines as Potential Antitubercular Agents. J. Appl. Sci. 2004, 4, 302-307.

(16) Pandey, V. K.; Tusi, S.; Tusi, Z.; Raghubir, R.; Dixit, M.; Joshi, M. N.; Bajpai, S. K. Thiadiazolyl quinazolones as potential antiviral and antihypertensive agents. Indian J. Chem. 2004, 43B, 180-183.

(17) Decker, M. Novel inhibitors of acetyl- and butyrylcholinesterase derived from the alkaloids dehydroevodiamine and rutaecarpine. Eur. J. Med. Chem. 2005, 40, 305-313.

(18) Rashmi, A.; Ashish, K; Gill, N. S.; Rana, A. C. Quinazolinone: an overview. Int. Res. J. Pharm. 2011, 2, 22-28.

(19) Malamas, M. S.; Millen, J. Quinazolineacetic acids and related analogs as aldose reductase inhibitors. J. Med. Chem. 1991, 34, 14921503.

(20) Toosi, F. S.; Khakzadi, M. A new and facile synthesis 2,3dihydroquinazolin-4(1H)-ones. Res. Chem. Intermed. 2015, 41, 311317.

(21) Gupta, T.; Rohilla, A.; Pathak, A.; Akhtar, J.; Haider, R.; Yar, S. Current perspectives on quinazolines with potent biological activities: A review. Synth. Commun. 2018, 1099.

(22) Hameed, A.; Al-Rashida, M; Uroos, M.; Ali, S. A.; Arshia; Ishtiaq, M.; Khan, K. M. Quinazoline and quinazolinone as important medicinal scaffolds: a comparative patent review (2011-2016). Expert Opin. Ther. Pat. 2018, 281.

(23) Wu, X.-F.; Oschatz, S.; Block, A.; Spannenberg, A.; Langer, P. Base mediated synthesis of 2-aryl-2,3-dihydroquinazolin-4(1H)-ones from 2-aminobenzonitriles and aromatic aldehydes in water. Org. Biomol. Chem. 2014, 12, 1865-1870.

(24) Tarannum, S.; Ahmed, N.; Siddiqui, Z. N. LaCl3/nano-SiO2: A novel nanocatalyst for efficient synthesis of functionalized 2, 3dihydroquinazolinones. Catal. Commun. 2015, 66, 60-66.

(25) Zhang, S. G.; Xie, Z. B.; Liu, L. S.; Liang, M.; Le, Z. G. Synthesis of 2,3-dihydroquinazolin-4(1 $\mathrm{H})$-ones catalyzed by $\alpha$-chymotrypsin. Chin. Chem. Lett. 2017, 28, 101-104.

(26) Davoodnia, A.; Khashi, M. Cerium (IV) sulfate: A highly efficient reusable heterogeneous catalyst for the one-pot synthesis of 2,3dihydroquinazolin- $4(1 \mathrm{H})$-ones under solvent-free conditions. Chin. J. Catal. 2014, 35, 1054-1058.

(27) Safari, J.; Gandomi-Ravandi, S. Microwave-accelerated three components cyclocondensation in the synthesis of 2,3-dihydroquinazolin-4(1H)-ones promoted by Cu-CNTs. J. Mol. Catal. A: Chem. 2013, $371,135-140$.

(28) Lobo, H. R.; Singh, B. S.; Shankarling, G. S. Bio-compatible eutectic mixture for multi-component synthesis: A valuable acidic catalyst for synthesis of novel 2,3-dihydroquinazolin-4(1H)-one derivatives. Catal. Commun. 2012, 27, 179-183.

(29) Niknam, K.; Mohammadizadeh, M. R.; Mirzaee, S. Silica-bonded S-sulfonic Acid as a Recyclable Catalyst for Synthesis of 2,3Dihydroquinazolin-4(1H)-ones. Chin. J. Chem. 2011, 29, 1417-1422.

(30) Niknam, K.; Jafarpour, N.; Niknam, E. Silica-bonded Npropylsulfamic acid as a recyclable catalyst for the synthesis of 2,3dihydroquinazolin-4(1H)-ones. Chin. Chem. Lett. 2011, 22, 69-72.
(31) Shaterian, H. R.; Oveisi, A. R.; Honarmand, M. Synthesis of 2,3Dihydroquinazoline-4(1H)-ones. Synth. Commun. 2010, 40, 12311242.

(32) Bansal, A. K.; Bilaspuri, G. S. Impacts of oxidative stress and antioxidants on semen functions. Vet. Med. Int. 2011, 686137.

(33) Zishan, M.; Ahmad, Z.; Idris, S.; Parveen, Z.; Hussain, W. Diabetes mellitus: Role of free radicals and oxidative stress. World J. Pharm. Pharm. Sci. 2017, 6, 448-470.

(34) Asmat, U.; Abad, K.; Ismail, K. Diabetes mellitus and oxidative stress - A concise review. Saudi Pharm. J. 2016, 24, 547-553.

(35) Sheikhpour, R. Diabetes and Oxidative Stress: The Mechanism and Action. Iran. J. Diabetes Obes. 2013, 5, 40-45.

(36) Oberley, L. W. Free radicals and diabetes. Free Radical Biol. Med. 1988, 5, 113-124.

(37) Paseban, M.; Butler, A. E.; Sahebkar, A. Mechanisms of statininduced new-onset diabetes. J. Cell. Physiol. 2019, 234, 12551-12561.

(38) Wang, S.; Cai, R.; Yuan, Y.; Varghese, Z.; Moorhead, J.; Ruan, X. $Z$. Association between reductions in low-density lipoprotein cholesterol with statin therapy and the risk of new-onset diabetes: a meta-analysis. Sci. Rep. 2017, 7, 39982.

(39) Huang, S.-S.; Su, S.-Y.; Chang, J.-S.; Lin, H.-J.; Wu, W.-T.; Deng, J.-S.; Huang, G.-J. Antioxidants, anti-inflammatory, and antidiabetic effects of the aqueous extracts from Glycine species and its bioactive compounds. Med. Chem. Res. 2016, 57, 38.

(40) Russo, D.; Valentão, P.; Andrade, P. B.; Fernandez, E. C.; Milella, L. Evaluation of Antioxidant, Antidiabetic and Anticholinesterase Activities of Smallanthus sonchifolius Landraces and Correlation with Their Phytochemical Profiles. Int. J. Mol. Sci. 2015, 16, 17696-17718.

(41) Sheela, A.; Sarada, N. C.; Vijayaraghavan, R. A possible correlation between antioxidant and antidiabetic potentials of oxovanadium(IV) complexes. Med. Chem. Res. 2013, 22, 2929-2937.

(42) Sarian, M. N.; Ahmed, Q. U.; So'Ad, S. Z. M.; Alhassan, A. M.; Murugesu, S.; Perumal, V.; Syed Mohamad, S. N. A.; Khatib, A.; Latip, J. Antioxidant and antidiabetic effects of flavonoids: A structure-activity relationship based study. BioMed Res. Int. 2017, 1-14.

(43) Nabipour, I.; Mohebbi, G.; Vatanpour, H.; Vazirizadeh, A. Hematological parameters on the effect of the jellyfish venom Cassiopea andromeda in animal models. Data in Brief. 2017, 11, 517-521.

(44) Ajagbonna, O. P.; Onifade, K. I.; Suleiman, U. Haematological and biochemical changes in rats given extract of Calotropis procera. Sokoto J. Vet. Sci. 1999, 1, 36-42.

(45) Mansi, K.; Lahham, J. Effects of Artemisia sieberi Besser (a. herba-alba) on heart rate and some hematological values in normal and alloxan-induced diabetic rats. J. Basic Appl. Sci. 2008, 4, 57-62.

(46) Kelkar, G.; Subhadra, K.; Chengappa, R. K. Effect of Antioxidant Supplementation on Hematological Parameters, Oxidative Stress and Performance of Indian Athletes. J. Hum. Ecol. 2008, 24, 209-213.

(47) Pisoschi, A. M.; Negulescu, G. P. Methods for Total Antioxidant Activity Determination: A Review. Anal. Bioanal. Chem. 2011, 1, 106.

(48) David, J.; Barreiros, A.; David, J. Antioxidant Phenylpropanoid Esters of triterpenes fromDioclea lasiophylla. Pharm. Biol. 2008, 42, $36-38$.

(49) Plaza, M.; Pozzo, T.; Liu, J.; Ara, K. Z. G.; Turner, C.; Karlsson, E. N. Substituent Effects on in Vitro Antioxidizing Properties, Stability, and Solubility in Flavonoids. J. Agric. Food Chem. 2014, 62, 3321-3333.

(50) Ichikawa, K.; Sasada, R.; Chiba, K.; Gotoh, H. Effect of Side Chain Functional Groups on the DPPH Radical Scavenging Activity of Bisabolane-Type Phenols. Antioxidants 2019, 8, 65.

(51) Broggi, J.; Terme, T.; Vanelle, P. Organic Electron Donors as Powerful Single-Electron Reducing Agents in Organic Synthesis. Angew. Chem., Int. Ed. 2014, 53, 384-413.

(52) Campanella, L.; Martini, E.; Rita, G.; Tomassetti, M. Antioxidant capacity of dry vegetal extracts checked by voltammetric method. J. Food, Agric. Environ. 2006, 4, 135-144.

(53) Antolovich, M.; Prenzler, P. D.; Patsalides, E.; McDonald, S.; Robards, K. Methods for testing antioxidant activity. Analyst 2002, 127, 183-198. 
(54) Tong, X.-G.; Zhou, L.-L.; Wang, Y.-H.; Xia, C.; Wang, Y.; Liang, M.; Hou, F.-F.; Cheng, Y.-X. Acortatarins A and B, Two Novel Antioxidative Spiroalkaloids with a Naturally Unusual Morpholine Motif from Acorus tatarinowii. Org. Lett. 2010, 12, 1844-1847.

(55) Sudhakar, G.; Kadam, V. D.; Bayya, S.; Pranitha, G.; Jagadeesh, B. Total Synthesis and Stereochemical Revision of Acortatarins A and B. Org. Lett. 2011, 13, 5452-5455.

(56) Lawal, B.; Shittu, O. K.; Rotimi, A. A.; Olalekan, I. A.; Kamooru, A. A.; Ossai, P. C. Effect of Methanol Extract of Telfairia occcidentalis on Haematological Parameters in Wister Rats. J. Med. Sci. 2015, 15, 246-250.

(57) Mishra, N.; Tandon, V. Haematological effects of aqueous extract of ornamental plants in male Swiss albino mice. Vet. World. 2012, 5, $19-23$.

(58) Habib, N. S.; Ismail, K. A.; El-Tombary, A. A.; Abdel-Aziem, T. Antilipidemic agents, Part. IV: Synthesis and antilipidemic testing of some heterocyclic derivatives of hexadecyl and cyclohexyl hemisuccinate esters. Pharmazie 2000, 55, 495-499.

(59) Ganguli, S.; Firdous, M.; Maity, T. S.; Bera, R. K.; Panigrahi, M. The Study of Antihyperlipidemic Activities Of Schiff Bases Of 4(3h) Quinazolinone Derivatives In Rats. Int. J. Pharm. Pharm. Sci. 2011, 4, $175-178$.

(60) Kurogi, Y.; Inoue, Y.; Tsutsumi, K.; Nakamura, S.; Nagao, K.; Yoshitsugu, H.; Tsuda, Y. Synthesis and Hypolipidemic Activities of Novel 2-[4-[(Diethoxyphosphoryl)methyl]phenyl] quinazolines and 4(3H)-Quinazolinones. J. Med. Chem. 1996, 39, 1433-1437.

(61) Kusunoki, M.; Tsutsumi, K.; Iwata, K.; Yin, W.; Nakamura, T.; Ogawa, H.; Nomura, T.; Mizutani, K.; Futenma, A; Utsumi, K.; Miyata, T. NO-1886 (ibrolipim), a lipoprotein lipase activator, increases the expression of uncoupling protein 3 in skeletal muscle and suppresses fat accumulation in high-fat diet-induced obesity in rats. Metabolism 2005, $54,1587-1592$.

(62) Refaie, F. M.; Esmat, A. Y.; Gawad, S. M. A.; Ibrahim, A. M.; Mohamed, M. A. The antihyperlipidemic activities of $4(3 \mathrm{H})$ quinazolinone and two halogenated derivatives in rats. Lipids Health Dis. 2005, 4, 22.

(63) Kathiravan, M. K.; Vidyasagar, N.; Khiste, R.; Chote, A.; Jain, K. Synthesis and antihyperlipidemic activity of some novel 4-substituted2 -substitutedmethyltriazino[6,1-b]quinazolin-10-ones and 2,4-disubstituted-6,7-dimethoxy quinazoline. Arabian J. Chem. 2016, 9, S395S403.

(64) Kamran, H.; Kupferstein, E.; Sharma, N.; Karam, J. G.; Myers, A. K.; Youssef, I.; Sowers, J. R.; Gustafson, D. R.; Salifu, M. O.; McFarlane, S. I. Statins and New-Onset Diabetes in Cardiovascular and Kidney Disease Cohorts: A Meta-Analysis. CardioRenal Med. 2018, 8, 105112.

(65) Simonen, P. P.; Gylling, H. K.; Miettinen, T. A. Diabetes contributes to cholesterol metabolism regardless of obesity. Diabetes Care 2002, 25, 1511-5.

(66) Jahan, S.; Fatima, A.; Alam, I.; Ullah, A.; Rehman, H.; Afsar, T.; Almajwal, A.; Razak, S. Effects of dietary supplements on selected hematological and biochemical parameters of Pakistani athletes. BMC Nutr. 2018, 4, 41.

(67) Tsamesidis, I.; Pantaleo, A.; Pekou, A.; Gusani, A.; Iliadis, S.; Makedou, K.; Manca, A.; Carruale, A.; Lymperaki, E.; Fozza, C. Correlation of Oxidative Stress Biomarkers and Hematological Parameters in Blood Cancer Patients from Sardinia, Italy. Int. J. Hematol. Oncol. Stem. Cell. Res. 2019, 13, 49-57.

(68) Oyedemi, S. O.; Yakubu, M. T.; Afolayan, A. J. Antidiabetic activities of aqueous leaves extract of Leonotis leonurus in streptozotocin induced diabetic rats. J. Med. Plant Res. 2011, 5, 119125.

(69) Tsompos, C.; Panoulis, C.; Toutouzas, K.; Zografos, G.; Papalois, A. The Effect of the Antioxidant Drug "U-74389G" on Creatinine Levels during Ischemia Reperfusion Injury in Rats. Curr. Urol. 2016, 9, 73-78.

(70) Dennis, J.; Witting, P. Protective Role for Antioxidants in Acute Kidney Disease. Nutrients 2017, 9, 718.
(71) Akhtar, M. S.; Iqbal, J. Evaluation of the hypoglycaemic effect of Achyranthes aspera in normal and alloxan-diabetic rabbits. J. Ethnopharmacol. 1991, 31, 49-57.

(72) Stanely, P.; Prince, M.; Menon, V. P. Hypoglycaemic and other related actions of Tinospora cordifolia roots in alloxan-induced diabetic rats. J. Ethnopharmacol. 2000, 70, 9-15.

(73) Auwal, M. S.; Saka, S.; Shuaibu, A.; Mairiga, I. A.; Sanda, K. A.; Ibrahim, A.; Lawan, F. A.; Thaluvwa, A. B.; Njobdi, A. B. Phytochemical Properties and Hypoglycemic Activity of the Aqueous and Fractionated Portions of Acacia nilotica (Fabaceae) Pod Extracts on Blood Glucose Level in Normoglycemic Wistar Albino Rats. J. Med. Sci. 2013, 13, 111117.

(74) Brunmair, B.; Lehner, Z.; Stadlbauer, K.; Adorjan, I.; Frobel, K.; Scherer, T.; Luger, A.; Bauer, L.; Fürnsinn, C. 55P0110, a Novel Synthetic Compound Developed from a Plant Derived Backbone Structure, Shows Promising Anti-Hyperglycaemic Activity in Mice. PLoS One 2015, 10, No. e0126847.

(75) Eskandani, M.; Bahadori, M. B.; Zengin, G.; Dinparast, L.; Bahadori, S. Novel Natural Agents from Lamiaceae Family: An Evaluation on Toxicity and Enzyme Inhibitory Potential Linked to Diabetes Mellitus. Curr. Bioact. Compd. 2016, 12, 34-38.

(76) Gurram, V.; Garlapati, R.; Thulluri, C.; Madala, N.; Kasani, K. S.; Machiraju, P. K.; Doddapalla, R.; Addepally, U.; Gundla, U.; Patro, B.; Pottabathini, N. Design, synthesis, and biological evaluation of quinazoline derivatives as $\alpha$-glucosidase inhibitors. Med. Chem. Res. 2015, 24, 2227-2237.

(77) Wei, M.; Chai, W. M.; Wang, R.; Yang, Q.; Deng, Z.; Peng, Y. Quinazolinone derivatives: Synthesis and comparison of inhibitory mechanisms on $\alpha$-glucosidase. Bioorg. Med. Chem. 2017, 25, 13031308.

(78) Zhang, Y.; Gao, H.; Liu, R.; Liu, J.; Chen, L.; Li, X.; Zhao, L.; Wang, W.; Li, B. Quinazoline-1-deoxynojirimycin hybrids as high active dual inhibitors of EGFR and $\alpha$-glucosidase. Bioorg. Med. Chem. Lett. 2017, 27, 4309-4313.

(79) Babar, A.; Yar, M.; Tarazi, H.; Duarte, V.; Alshammari, M. B.; Gilani, M. A.; Iqbal, H.; Munawwar, M. A.; Alves, M. J.; Khan, A. F. Molecular docking and glucosidase inhibition studies of novel $\mathrm{N}$ arylthiazole-2-amines and Ethyl 2-[aryl(thiazol-2-yl)amino]acetates. Med. Chem. Res. 2017, 26, 3247-3261.

(80) Garlapati, R.; Pottabathini, N.; Gurram, V.; Kasani, S. K.; Gundla, R.; Thulluri, C.; Machiraju, P. K.; Chaudhary, A. B.; Addepally, U.; Dayam, R.; Chunduri, V. R.; Patro, B. Development of $\alpha$-glucosidase inhibitors by room temperature $\mathrm{C}-\mathrm{C}$ cross couplings of quinazolinones. Org. Biomol. Chem. 2013, 11, 4778-4791.

(81) Burits, M.; Bucar, F. Antioxidant activity of Nigella sativa essential oil. Phytother Res. 2000, 14, 323-328.

(82) Ansari, A. Q.; Ahmed, S. A.; Waheed, M. A.; Juned, S. A. Extraction and determination of antioxidant activity of Withania somnifera Dunal. Euro. J. Exp Bio. 2013, 3, 502-507.

(83) Heidarian, E.; Soofiniya, Y. Hypolipidemic and hypoglycemic effects of aerial part of Cynara scolymus in streptozotocin-induced diabetic rats. J. Med. Plant Res. 2011, 5, 2717-2723.

(84) Dinparast, L.; Valizadeh, H.; Bahadori, M. B.; Soltani, S.; Asghari, B.; Rashidi, M. R. Design, synthesis, $\alpha$-glucosidase inhibitory activity, molecular docking and QSAR studies of benzimidazole derivatives. J. Mol. Struct. 2016, 1114, 84-94. 